\title{
Synthesis and reactivity of ruthenium tetrazolate complexes containing a tris(pyrazolyl)borato (Tp) ligand
}

\author{
Yih-Hsing Lo ${ }^{\text {a }}$, Ying-Chih Lin ${ }^{\text {b,* }}$, Chiung-Cheng Huang ${ }^{b}$ \\ a Department of Chemical Engineering, Tatung University, Taipei 104, Taiwan, ROC \\ ${ }^{\mathrm{b}}$ Department of Chemistry, National Taiwan University, Taipei 106, Taiwan, ROC
}

Received 26 July 2007; received in revised form 12 October 2007; accepted 16 October 2007

Available online 22 October 2007

\begin{abstract}
Facile ligand substitutions are observed when the neutral ruthenium cyclopropenyl complex $(\mathrm{PPh})[\mathrm{Ru}] \mathrm{C}=\mathrm{C}(\mathrm{Ph}) \mathrm{CHCN}$ $\left(1,[\mathrm{Ru}]=\mathrm{Tp}\left(\mathrm{PPh}_{3}\right) \mathrm{Ru}\right)$ is treated with $\mathrm{MeCN}$ and pyrazole yielding the nitrile substituted ruthenium cyclopropenyl complex $(\mathrm{MeCN})[\mathrm{Ru}] \mathrm{C}=\mathrm{C}(\mathrm{Ph}) \mathrm{CHCN}(\mathbf{4 a})$ and the ruthenium metallacyclic pyrazole complex $\left(\mathrm{C}_{3} \mathrm{H}_{3} \mathrm{NN}\right)[\mathrm{Ru}] \mathrm{C}=\mathrm{C}(\mathrm{Ph}) \mathrm{CH}{ }_{2} \mathrm{CN}(7 \mathbf{a})$, respectively. The reactions of $\mathrm{Me}_{3} \mathrm{SiN}_{3}$ with $\mathbf{1}, \mathbf{4 a}$ and $\mathbf{7 a}$ are investigated. Treatment of 1 with $\mathrm{Me}_{3} \mathrm{SiN}_{3}$ affords in high yield the cationic $\mathrm{N}$-coordinated nitrile complex $\left\{\left(\mathrm{PPh}_{3}\right)[\mathrm{Ru}] \mathrm{NCCH}(\mathrm{Ph}) \mathrm{CH}_{2} \mathrm{CN}\right\} \mathrm{N}_{3}(\mathbf{3})$. Interestingly, the reaction of $4 \mathbf{a}$ with $\mathrm{Me}_{3} \mathrm{SiN}_{3}$ in $\mathrm{CH}_{2} \mathrm{Cl}_{2}$ in the presence of $\mathrm{NH}_{4} \mathrm{PF}_{6}$ results in an insertion of four nitrogen atoms into the $\mathrm{Ru}-\mathrm{C}_{\alpha}$ bond to form a diastereomeric mixture of the bright yellow zwitterionic tetrazolate complex $(\mathrm{MeCN})[\mathrm{Ru}]-\mathrm{N}_{4} \mathrm{CCH}(\mathrm{Ph}) \mathrm{CH}_{2} \mathrm{CN}(\mathbf{6 a})$ in a 3:2 ratio. The reaction of 7a with $\mathrm{Me}_{3} \mathrm{SiN}{ }_{3}$ gives the zwitterionic tetrazolate complex $\left(\mathrm{C}_{3} \mathrm{H}_{3} \mathrm{NNH}\right)[\mathrm{Ru}]-\mathrm{N}_{4} \mathrm{CCH}(\mathrm{Ph}) \mathrm{CH}_{2} \mathrm{CN}$ (9a). The two cationic tetrazolate complexes $\left\{\left(\mathrm{C}_{3} \mathrm{H}_{3} \mathrm{NNH}\right)[\mathrm{Ru}]-\mathrm{N}_{4}(\mathrm{R}) \mathrm{CCH}(\mathrm{Ph}) \mathrm{CH}_{2} \mathrm{CN}\right\}^{+}\left(\mathbf{1 2 a}, \mathrm{R}=\mathrm{CH}_{3}, \mathbf{1 2} \mathbf{b}, \mathrm{R}=\mathrm{C}_{6} \mathrm{H}_{5} \mathrm{CH}_{2}\right)$ are prepared by electrophilic addition of organic halides to $9 \mathbf{a}$. All of the complexes are identified by spectroscopic methods as well as elemental analysis. Pathways for the synthesis of these compounds are proposed.

(C) 2007 Elsevier B.V. All rights reserved.
\end{abstract}

Keywords: Tris(pyrazolyl)borato; Ruthenium; Vinylidene; Azide; Cyclopropenyl; Tetrazolate

\section{Introduction}

Tris(pyrazoly)borate anion $\left(\mathrm{Tp}, \mathrm{HB}(\mathrm{pz})_{3}\right)$ has been introduced by Trofimenko as a ligand in the preparation of various transition metal complexes [1]. The development of Tp chemistry within group VIII has picked up the pace since then. The Tp ligand is often compared with the $\mathrm{Cp}$ $\left(\mathrm{Cp}=\eta^{5}-\mathrm{C}_{5} \mathrm{H}_{5}\right)$ ligand due to their charge and number of electrons donated in the formation of complex. Notwithstanding, differences in size and electronic properties are obvious. Thus the cone angle of $\mathrm{Tp}$ close to $180^{\circ}$ is well above the $100^{\circ}$ calculated for $\mathrm{Cp}$. The steric bulk of the Tp ligand appears to disfavor higher coordination numbers or bulky structure of the metal center [2]. The chemistry of

\footnotetext{
* Corresponding author.

E-mail address: yclin@ntu.edu.tw (Y.-C. Lin).
}

organometallic ruthenium complexes have been the focus of many recent investigations, such as asymmetric hydrogenation [3], olefin metathesis [4], and polymerization [5]. Metal-mediated processes in many instances make possible certain reactions, which are not feasible without the involvement of metal ions. It is therefore important to better understand how an organic moiety attached on the metal undergoes chemical transformation. We previously reported the synthesis of cyclopropenyl complexes of ruthenium through a deprotonation reaction of cationic vinylidene complexes [6]. The same approach could also be used for the synthesis of metal-coordinated azirinyl complexes from cationic metal isocyanide complexes [7]. Highly strained organic cyclopropene and azirine compounds are synthetically useful [8]. Participation of $d$ orbital of Ru metal may stabilize this highly strained organic moiety consisting of a three-membered ring thus making 
these complexes readily accessible for further exploitation for the preparation of organic molecules. For example, reactions of ruthenium azirinyl complexes with aldehyde or acetone gave oxazolinyl complexes [7]. The previously reported regiochemistry of the carbon-carbon bond formation in the photoreaction of organic azirine with carbonyl group is reversed [9]. Much of character of the chemistry of the $\left[\mathrm{Cp}\left(\mathrm{PPh}_{3}\right)_{2} \mathrm{Ru}\right]^{+}$fragment can be traced to strongly $\pi$-basic nature of the ruthenium center. Replacing $\mathrm{Cp}$ with $\mathrm{Tp}$ increases the basicity of the metal center further, and it has been argued that it also leads to more ideally octahedral hybridization [2].

Trimethylsilyl azide and sodium azide were used widely in organic or organometallic reactions [10]. Organic azides react with alkenes or alkynes giving triazoline or triazole compounds through a [3+2] cycloaddition [11]. However, for an efficient $[3+2]$ cycloaddition to give triazoles, the presence of an electron-withdrawing group is needed either at the alkyne or at the azide part. Coupling reaction between azide, such as $\mathrm{Me}_{3} \mathrm{SiN}_{3}$, with simple alkyne and allyl carbonates catalyzed by $\mathrm{Pd}^{0} / \mathrm{Cu}^{\mathrm{I}}$ was reported by Yamamoto and his co-workers [12] as an efficient method for the synthesis of triazoles. The azide reagent is also commonly used in the synthesis of metal complexes with N-heterocyclic ligand. A number of $\mathrm{N}$-coordinated $\mathrm{Fe}$ tetrazole derivatives were obtained by the reaction of sodium azide with the coordinated $\mathrm{CN}$ of the $\mathrm{N}$-coordinated iron nitrile complex. The mechanism probably involves nucleophilic attack of the azide anion to the carbon atom of the coordinated nitrile followed by cyclization [13].

During the course of investigations into ruthenium cyclopropenyl chemistry, we previously established the formation of interesting neutral ruthenium tetrazolate complex [14]. For example, the cyclopropenyl complex $\mathrm{Cp}\left(\mathrm{PPh}_{3}\right)_{2} \mathrm{Ru}-\mathrm{C}=\mathrm{C}(\mathrm{Ph}) \mathrm{CHCN}$ was found to react with an excess amount of $\mathrm{Me}_{3} \mathrm{SiN}_{3}$ to afford the zwitterionic tetrazolate complex $\mathrm{Cp}\left(\mathrm{PPh}_{3}\right)_{2} \mathrm{Ru}-\mathrm{N}_{4} \mathrm{CCH}(\mathrm{Ph}) \mathrm{CH}_{2} \mathrm{CN}$. We thought similar complex containing a $\mathrm{Tp}$ ligand would be a logical extension. Herein, we report preparation of several zwitterionic Tp ruthenium tetrazolate complexes. Electrophilic addition to the zwitterionic $\mathrm{Tp}$ ruthenium tetrazolate complex also affords new cationic complex. This study again shows that the Tp ligand, while similar to the $\mathrm{Cp}$ ligand in many ways, creates a new and unique chemistry for exploration.

\section{Results and discussion}

\subsection{Reaction of 1 with $\mathrm{Me}_{3} \mathrm{SiN}_{3}$}

The reaction of the Tp ruthenium cyclopropenyl complex $\left(\mathrm{PPh}_{3}\right)[\mathrm{Ru}]-\mathrm{C}=\mathrm{C}(\mathrm{Ph}) \mathrm{CH}-\mathrm{CN} \quad\left(\mathbf{1},[\mathrm{Ru}]=\mathrm{Tp}\left(\mathrm{PPh}_{3}\right)-\right.$ $\mathrm{Ru}$ ) with a fivefold excess of $\mathrm{Me}_{3} \mathrm{SiN}_{3}$ in $\mathrm{CH}_{2} \mathrm{Cl}_{2}$ at room temperature lead to the formation of the cationic $\mathrm{N}$-coordinated nitrile complex $\left\{\left(\mathrm{PPh}_{3}\right)[\mathrm{Ru}] \mathrm{NCCH}(\mathrm{Ph}) \mathrm{CH}_{2}-\right.$ $\mathrm{CN}\} \mathrm{N}_{3}(3)$ as a light yellow powder in $63 \%$ yield (Scheme 1). Complex 3 is soluble in polar solvent such as $\mathrm{CHCl}_{3}$,
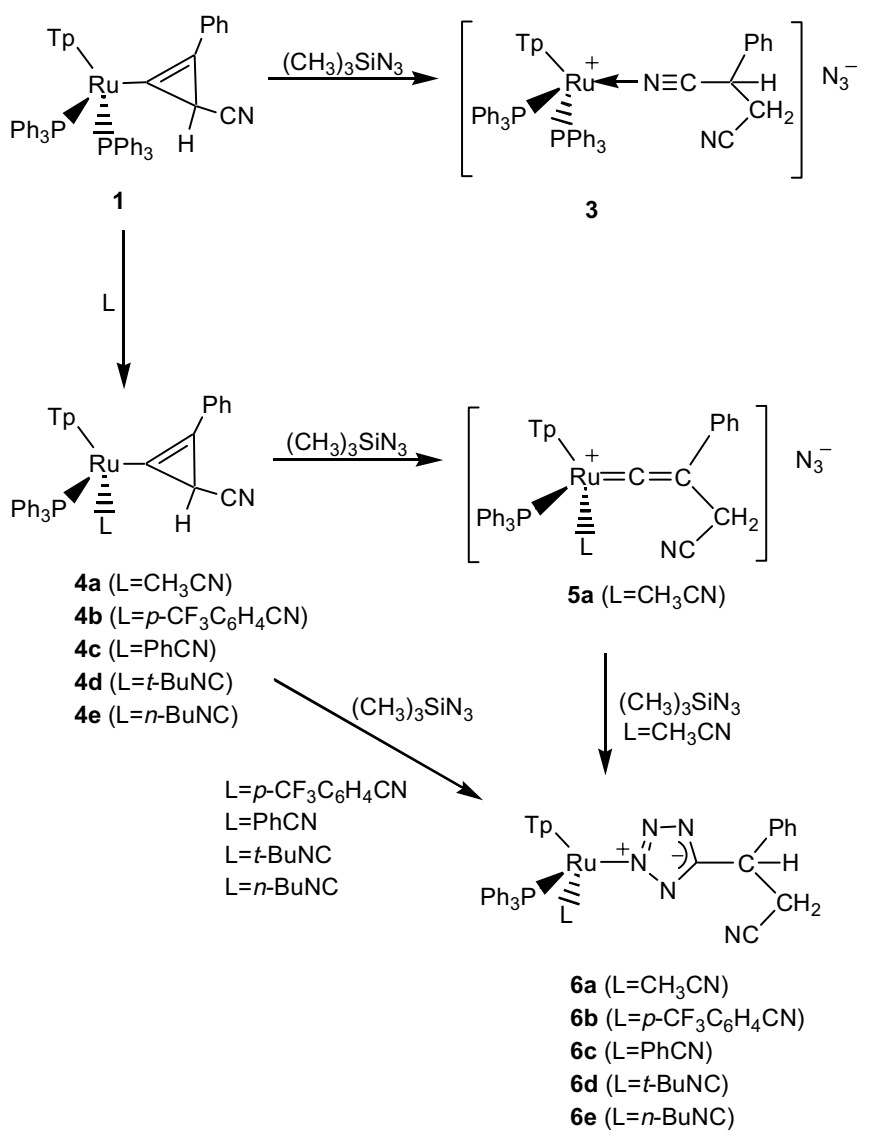

Scheme 1.

THF, $\mathrm{CH}_{3} \mathrm{OH}$ and $\mathrm{CH}_{3} \mathrm{CN}$ but insoluble in ether and hexane. In a separate experiment, a green colored intermediate was acquired at $0{ }^{\circ} \mathrm{C}$ as the major product, along with a small amount of complex 3 . The reaction carried out at $0{ }^{\circ} \mathrm{C}$ for $5 \mathrm{~h}$ in the presence of $\mathrm{NH}_{4} \mathrm{PF}_{6}$ gave a green solution from which an intermediate with counter anion $\mathrm{PF}_{6}^{-}$ could be isolated in high yield. In the absence of $\mathrm{NH}_{4} \mathrm{PF}_{6}$ the intermediate is proposed as the cationic vinylidene complex $\left\{\left(\mathrm{PPh}_{3}\right)[\mathrm{Ru}]=\mathrm{C}=\mathrm{C}(\mathrm{Ph}) \mathrm{CH}_{2} \mathrm{CN}\right\} \mathrm{N}_{3}$ (2). Complex 2 is unstable in solution at room temperature and undergoes a further reaction with $\mathrm{Me}_{3} \mathrm{SiN}_{3}$ to give 3 , which is stable in solution. Complex 2 can be isolated in a stable form by replacing the counter anion $\mathrm{N}_{3}^{-}$by $\mathrm{PF}_{6}^{-}$. Trace of water in $\mathrm{CH}_{2} \mathrm{Cl}_{2}$ is believed to act as the source of protons that are incorporated into the product through hydrolysis of the $\mathrm{Me}_{3} \mathrm{Si}$ group derived from addition of $\mathrm{Me}_{3} \mathrm{SiN}_{3}$ to the three-membered ring. From the reaction mixture $\mathrm{Me}_{3} \mathrm{SiOH}$ was also distilled off with $\mathrm{CH}_{2} \mathrm{Cl}_{2}$ and was identified by mass spectrometry. The characteristic spectroscopic data of $\mathbf{2}$ consist of a strongly deshielded $\mathrm{C}_{\alpha}$ resonance as a triplet at $\delta 375.3$ with $J_{\mathrm{P}-\mathrm{C}}=16.5 \mathrm{~Hz}$ in the ${ }^{13} \mathrm{C}$ NMR spectrum and a singlet ${ }^{31} \mathrm{P}$ NMR resonance at $\delta 36.5$ in $\mathrm{CDCl}_{3}$ at $0{ }^{\circ} \mathrm{C}$, which is due to fluxional behavior of the vinylidene ligand [6]. For comparison, the spectroscopic data of the $\mathrm{Cp}$ analogue are similar; the triplet $\mathrm{C}_{\alpha}$ resonance appears at $\delta 345.6$ with $J_{\mathrm{P}-\mathrm{C}}=17.9 \mathrm{~Hz}$ in the ${ }^{13} \mathrm{C}$ NMR spectrum and a singlet ${ }^{31} \mathrm{P}$ NMR resonance 
is observed at $\delta 42.4$ [6a]. Formation of 2 occurs by selective cleavage of the cyclopropenyl $\mathrm{C}-\mathrm{C}$ single bond near the metal center. This selectivity is similar to that reported for the unsymmetrical cyclopropenes where the single $\mathrm{C}-\mathrm{C}$ bond with a metal-substituent is cleaved [6a]. The ${ }^{31} \mathrm{P}$ NMR spectrum of $\mathbf{3}$ displays two doublet resonances at $\delta$ 39.1 and 38.7 with $J_{\mathrm{P}-\mathrm{P}}=29.4 \mathrm{~Hz}$ assigned to the two $\mathrm{PPh}_{3}$ ligands owing to the presence of a diastereotopic center in the $\mathrm{N}$-coordinated nitrile ligand. In the ${ }^{1} \mathrm{H}$ NMR spectrum, the same pattern, i.e. a two multiplet resonance at $\delta 3.41$ and 3.05 assigned to the diastereotopic $\mathrm{CH}_{2}$ group is consistent with the ${ }^{31} \mathrm{P}$ NMR data. The $\mathrm{C} \equiv \mathrm{N}$ stretching of $\mathrm{N}$-coordinated nitrile ligand of $\mathbf{3}$ in IR spectrum appears at $2253 \mathrm{~cm}^{-1}$. In the $\mathrm{FAB}$ mass spectrum of $\mathbf{3}$, the parent peak for the cationic complex is observed at $\mathrm{m} / \mathrm{z}=995.1$ indicating addition of one nitrogen atom and two hydrogen atoms to $\mathbf{1}$. On the basis of these data, it is clear that the nitrile ligand is coordinated to the $\left[\mathrm{Tp}\left(\mathrm{PPh}_{3}\right)_{2} \mathrm{Ru}\right]^{+}$moiety via the nitrogen atom. Conversion of a vinylidene precursor to N-coordinated nitrile by hydrazine, an organometallic Beckmann rearrangement, has been reported in an iron system [15].

\subsection{Reaction of cyclopropenyl complexes with $\mathrm{Me}_{3} \mathrm{SiN}_{3}$}

We previously reported [6] the analogous Cp complex of 1, which is stable with respect to the ligand substitution reaction making the coordination site of $\mathbf{1}$ unavailable for an incoming substrate. In contrast, the Tp complex $\mathbf{1}$ is susceptible to ligand substitution reaction under relatively mild conditions. This may be attributed to the increased steric bulk of the $\mathrm{Tp}$ ligand relative to the $\mathrm{Cp}$. For example, when 2 equiv. of $\mathrm{PhCN}, p-\mathrm{CF}_{3} \mathrm{C}_{6} \mathrm{H}_{4} \mathrm{CN}, n-\mathrm{BuNC}$ or $t$-BuNC were added at room temperature to a $\mathrm{CH}_{2} \mathrm{Cl}_{2}$ solution of 1 a smooth reaction ensued over $1 \mathrm{~h}$ affording good yields of various bright yellow cyclopropenyl complexes $(\mathrm{L})[\mathrm{Ru}] \mathrm{C}=\mathrm{C}(\mathrm{Ph}) \mathrm{CHCN}(\mathbf{4 a}, \mathrm{L}=\mathrm{MeCN} ; \mathbf{4 b}$, $\mathrm{L}=p-\mathrm{CF}_{3} \mathrm{C}_{6} \mathrm{H}_{4} \mathrm{CN} ; \mathbf{4 c}, \mathrm{L}=\mathrm{PhCN} ; \mathbf{4 d}, \mathrm{L}=t-\mathrm{BuNC} ; \mathbf{4 e}$, $\mathrm{L}=n$-BuNC), respectively. Treatment of complex $\mathbf{4 a}$ with a fivefold excess of $\mathrm{Me}_{3} \mathrm{SiN}_{3}$ in $\mathrm{CH}_{2} \mathrm{Cl}_{2}$ in the presence of $\mathrm{NH}_{4} \mathrm{PF}_{6}$ at room temperature for $24 \mathrm{~h}$ results in a ringopening reaction followed by the insertion of four nitrogen atoms into the $\mathrm{Ru}-\mathrm{C}_{\alpha}$ bond to form the yellow zwitterionic tetrazolate complex $(\mathrm{MeCN})[\mathrm{Ru}]-\mathrm{N}_{4} \mathrm{CCH}(\mathrm{Ph}) \mathrm{CH}_{2} \mathrm{CN}$ (6a) (Scheme 1). A series of successive color changes were noted during the course of the reaction. The light yellow solution of 4a first turned deep green upon addition of $\mathrm{Me}_{3} \mathrm{SiN}_{3}$ at room temperature, and subsequently turned light yellow after $10 \mathrm{~h}$ and then yellow after $24 \mathrm{~h}$. In both reactions of 1 and $4 \mathbf{a}$ with $\mathrm{Me}_{3} \mathrm{SiN}_{3}$, addition of $\mathrm{D}_{2} \mathrm{O}$ to $\mathrm{CH}_{2} \mathrm{Cl}_{2}$ led to incorporation of two deuterium atoms at two vicinal carbon atoms of both $\mathbf{3}$ and $\mathbf{6 a}$. The green vinylidene intermediate $\left\{(\mathrm{MeCN})[\mathrm{Ru}]=\mathrm{C}=\mathrm{C}(\mathrm{Ph}) \mathrm{CH}_{2}\right.$ $\mathrm{CN}\} \mathrm{N}_{3}(\mathbf{5 a})$ could also be isolated from the reaction carried out at $0{ }^{\circ} \mathrm{C}$ for a shorter reaction time. However, no reaction was observed between $\{(\mathrm{MeCN})[\mathrm{Ru}=\mathrm{C}=\mathrm{C}(\mathrm{Ph})$ $\left.\mathrm{CH}_{2} \mathrm{CN}\right\} \mathrm{PF}_{6}$ and $\mathrm{Me}_{3} \mathrm{SiN}_{3}$. Significantly, the reaction of
$\left\{(\mathrm{MeCN})[\mathrm{Ru}]=\mathrm{C}=\mathrm{C}(\mathrm{Ph}) \mathrm{CH}_{2} \mathrm{CN}\right\} \mathrm{PF}_{6}$ with $\mathrm{NaN}_{3}$ can give a mixture of $5 \mathbf{a}$ and other unidentified products. Only in the presence of both $\mathrm{Me}_{3} \mathrm{SiN}_{3}$ and $\mathrm{NaN}_{3}$ the reaction of the vinylidene can afford 6a indicating the requirement of both the electrophile and nucleophile for the reaction to take place. This might be due to the covalent character of the $\mathrm{Si}-\mathrm{N}$ bond in $\mathrm{Me}_{3} \mathrm{SiN}_{3}$ and weak nucleophilicity of the vinylidene ligand of the cationic complex to cleave the $\mathrm{Si}-\mathrm{N}$ bond. The presence of a $\mathrm{Me}_{3} \mathrm{Si}$ group in the reaction system assists the ring-opening process. Thus the reaction of $\mathbf{4 a}$ with $\mathrm{Me}_{3} \mathrm{SiCl}$ in the presence of $\mathrm{NaN}_{3}$ gave a mixture of 5a and other unidentified products. For 5a with a $\mathrm{PF}_{6}$ counter anion, attempts to exchange the counter anion to a $\mathrm{N}_{3}$ anion led to decomposition of the vinylidene complex. To initiate a clean addition reaction at $\mathrm{C}_{\alpha}$ it is therefore essential to have the three-membered cyclopropenyl ring. The presence of a $\mathrm{Me}_{3} \mathrm{Si}$ group as an electrophile is also required for the opening of the three-membered ring. For complex 6a diastereomers in a 3:2 ratio are observed. The major and minor isomers display singlet ${ }^{31} \mathrm{P}$ NMR resonance at $\delta 53.1$ and 53.2 , respectively. In the ${ }^{1} \mathrm{H}$ NMR spectrum of $\mathbf{6 a}$, the dd resonance at $\delta 4.54$ and 4.49 are assigned to the methyne proton and two resonances displaying doublets of an $\mathrm{AB}$ pattern at $\delta 3.19$, 2.94 and $\delta 3.02,2.76$ are assigned to the diastereotopic methylene group of major and minor isomers, respectively. By comparing the spectroscopic data of $\mathbf{6 a}$ with that of the $\mathrm{Cp}$ analogue, it is clear that the organic ligands are the same [14].

Similarly, preparation of other zwitterionic tetrazolate complexes $(\mathrm{L})[\mathrm{Ru}]-\mathrm{N}_{4} \mathrm{CH}(\mathrm{Ph}) \mathrm{CH}_{2} \mathrm{CN} \quad\left(\mathbf{6 b}, \quad \mathrm{L}=p-\mathrm{CF}_{3^{-}}\right.$ $\mathrm{C}_{6} \mathrm{H}_{4} \mathrm{CN} ; 6 \mathbf{6}, \mathrm{L}=\mathrm{PhCN} ; 6 \mathbf{6 d}, \mathrm{L}=t$-BuNC; 6e, $\mathrm{L}=n$ BuNC) have all been accomplished with high yields by reacting a fivefold excess of $\mathrm{Me}_{3} \mathrm{SiN}_{3}$ with the corresponding $\mathrm{Tp}$ ruthenium cyclopropenyl complexes $\mathbf{4 b}-\mathbf{e}$, which were readily prepared from the reaction of $\mathbf{1}$ with corresponding reagents [6]. Significantly, when these reactions were repeated using only 1 equiv. of $\mathrm{Me}_{3} \mathrm{SiN}_{3}$ much lower yields of the product (ca. 15\%) were obtained. Complexes 6b-e all contain diastereomers in a 3:2 ratio. With the exception of $\mathbf{6 d}$, other tetrazolate complexes mentioned above are prepared in $\mathrm{CH}_{2} \mathrm{Cl}_{2}$ at room temperature. For the synthesis of $\mathbf{6 d}$, heating is required and a mixture of $\mathrm{CH}_{2} \mathrm{Cl}_{2} / \mathrm{CHCl}_{3}(3: 1 \mathrm{v} / \mathrm{v})$ was used as a solvent in order to achieve a slightly higher reaction temperature. Complexes 6a-e all display yellow color in their solid state. Interestingly, major isomers of $\mathbf{6 a}, \mathbf{6 b}$ and $\mathbf{6 c}$, are more stable than their corresponding minor isomer. Complexes $\mathbf{6 d}$ and $\mathbf{6 e}$ are stable in ether, and $\mathrm{THF}$, and in $\mathrm{CHCl}_{3}, \mathbf{6 a}, \mathbf{6 b}, \mathbf{6 c}$ and $\mathbf{6 d}$ are less stable than 6e. Furthermore, 6d decomposes in $\mathrm{CHCl}_{3}$ producing $(t-\mathrm{BuNC})[\mathrm{Ru}]-\mathrm{Cl}$ and other unidentifiable organic products. Decomposition of $\mathbf{6 a}, \mathbf{6 b}$ and $\mathbf{6 c}$ produces complicated mixture. The stability of substituted tetrazolate complexes are found to decrease in the following order: $n$ - $\mathrm{BuNC}>t$ - $\mathrm{BuNC}>p-\mathrm{CF}_{3} \mathrm{C}_{6} \mathrm{H}_{4} \mathrm{CN}>\mathrm{PhCN}>\mathrm{CH}_{3} \mathrm{CN}$. This could mean that a better $\pi$ accepter ligand makes 
the tetrazolate complex more stable which may be attributed to the strong trans influence of the Tp ligand.

\subsection{Possible mechanism for the formation of $\mathbf{3}$ and $\mathbf{6 a}$}

The reaction of 1 with $\mathrm{Me}_{3} \mathrm{SiN}_{3}$ leading to 3 may proceed via the following pathway. An electrophilic addition of the $\mathrm{Me}_{3} \mathrm{Si}$ group to the three-membered ring with concomitant ring-opening followed by hydrolysis of the added $\mathrm{Me}_{3} \mathrm{Si}$ group affords 2 containing an azide counter anion. This is followed by nucleophilic addition of the azide anion at $\mathrm{C}_{\alpha}$ of the resulting vinylidene ligand. Subsequent electrophilic addition of a second $\mathrm{Me}_{3} \mathrm{Si}$ group at $\mathrm{C}_{\beta}$ followed by loss of $\mathrm{N}_{2}$ is accompanied by a metal migration and hydrolysis of the $\mathrm{Me}_{3} \mathrm{Si}$ group to give the $\mathrm{N}$-coordinated nitrile complex 3 (Scheme 1). In the reaction of $\mathbf{4 a}$ with $\mathrm{Me}_{3} \mathrm{SiN}_{3}$, the reaction may proceed similarly in the first stage to give an analogue of $\mathbf{3}$. Formation of $\mathbf{6 a i s}$ then rationalized by a $[3+2]$ cycloaddition of the $\mathrm{C} \equiv \mathrm{N}$ bond with another azide anion followed by metal migration (linkage isomerization). A possible pathway via direct cyclization of the imine intermediate with azide anion to result in formation of $\mathbf{6 a}$ could also occur. In a previous study, organic tetrazole compound was synthesized via a $[3+2]$ cycloaddition reaction of a nitrile group with azide [16]. In some systems, cyclization was observed in the case of an imine compound with an azide group [16]. Additionally, tetrazole compounds resulted from attack of an azide to an imine compound with an appropriate leaving group followed by cyclization have also been reported [17]. The fact that compound 3 would not undergo further nucleophilic addition or cyclization is interpreted in terms of relatively larger steric hindrance of a $\mathrm{PPh}_{3}$ relative to the $\mathrm{MeCN}$ ligand. Interestingly, we have previously reported [6c] that the reaction of the analogous $\mathrm{Cp}$ complex of 1 with $\mathrm{Me}_{3} \mathrm{SiN}_{3}$ did not yield the $\mathrm{N}$-coordinated nitrile complex but rather the tetrazolate complex. This could mean that the steric bulk of the $\mathrm{Tp}$ ligand makes the $\mathrm{N}$-coordinated nitrile complex less reactive for further nucleophilic addition or cyclization. Metal-coordinated azide ligands undergo 1,3dipolar cycloaddition reactions with carbon-carbon and carbon-heteroatom multiple bonds. The metals involved in such reactions are $\mathrm{Pd}(\mathrm{II})$ [18], $\mathrm{Pt}(\mathrm{II})$ [19] or $\mathrm{Co}(\mathrm{III})$ [20]. although a whole range of other transition metals has been used. Formation of tetrazolate ring in 6a should not proceed via this pathway since the reaction of organic nitrile with $\left(\mathrm{CH}_{3} \mathrm{CN}\right)[\mathrm{Ru}]-\mathrm{N}_{3}$ does not yield $6 \mathbf{6}$.

\subsection{Reaction of metallacyclic complex with $\mathrm{Me}_{3} \mathrm{SiN}_{3}$}

The reaction of 1 with pyrazole in $\mathrm{CH}_{2} \mathrm{Cl}_{2}$ at room temperature did not yield the expected neutral substituted cyclopropenyl complex, but instead gave the metallacyclic complex $\quad\left(\mathrm{C}_{3} \mathrm{H}_{3} \mathrm{NN}\right)[\mathrm{Ru}]-\mathrm{C}=\mathrm{C}(\mathrm{Ph}) \mathrm{CH}_{2} \mathrm{CN} \quad$ (7a) see Scheme 2. At room temperature addition of excess $\mathrm{Me}_{3} \mathrm{SiN}_{3}$ to a $\mathrm{CH}_{2} \mathrm{Cl}_{2}$ solution of 7a leads to the formation of the tetrazolate complex $\left(\mathrm{C}_{3} \mathrm{H}_{3} \mathrm{NNH}\right)\left[\mathrm{Ru}-\mathrm{N}_{4} \mathrm{CCH}(\mathrm{Ph})\right.$ -

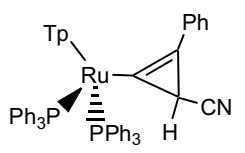

1
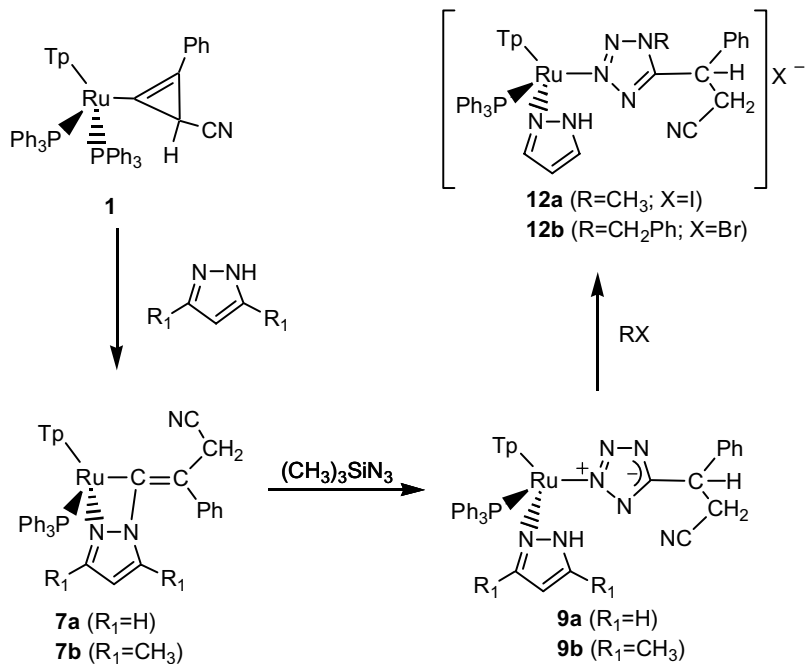

12a $\left(\mathrm{R}=\mathrm{CH}_{3} ; \mathrm{X}=\mathrm{I}\right)$
12b $\left(\mathrm{R}=\mathrm{CH}_{2} \mathrm{Ph} ; \mathrm{X}=\mathrm{Br}\right)$
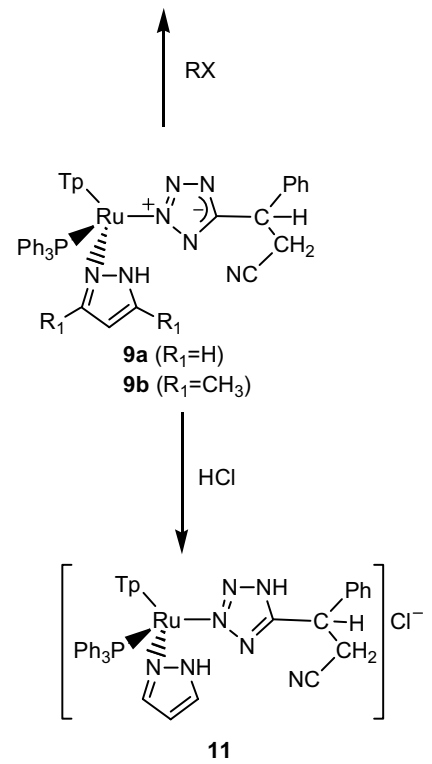

Scheme 2.

$\mathrm{CH}_{2} \mathrm{CN}$ (9a), obtained as a bright yellow powder in high yield (Scheme 2). Complex 9a contains two diastereomers in a 3:2 ratio and is soluble in $\mathrm{CH}_{2} \mathrm{Cl}_{2}$, THF, and ether. In the ${ }^{1} \mathrm{H}$ NMR spectrum of the mixture containing both major and minor isomers, two multiplet resonances displaying doublets of an $\mathrm{AB}$ pattern at $\delta 3.03,2.85$ and $\delta$ $3.12,2.93$ are assigned to two methylene groups, respectively. The major and minor isomers display singlet ${ }^{31} \mathrm{P}$ NMR resonances at $\delta 54.6$ and 54.1, respectively. The intermediate $\quad\left\{\left(\mathrm{C}_{3} \mathrm{H}_{3} \mathrm{NNH}\right)[\mathrm{Ru}]=\mathrm{C}=\mathrm{C}(\mathrm{Ph}) \mathrm{CH}_{2} \mathrm{CN}\right\} \mathrm{N}_{3}$ $\left(\mathbf{8 a}-\mathbf{N}_{3}\right)$ was observed in the initial stage of the reaction when the reaction is monitored by spectroscopic method. Reaction of $\left(\mathrm{Me}_{2} \mathrm{C}_{3} \mathrm{HNN}\right)\left[\mathrm{Ru}-\mathrm{C}=\mathrm{C}(\mathrm{Ph}) \mathrm{CH}_{2} \mathrm{CN}\right.$ (7b) with $\mathrm{Me}_{3} \mathrm{SiN}_{3}$ gives similar product $\left(\mathrm{Me}_{2} \mathrm{C}_{3} \mathrm{HNNH}\right)[\mathrm{Ru}]$ $\mathrm{N}_{4} \mathrm{CCH}(\mathrm{Ph}) \mathrm{CH}_{2} \mathrm{CN}$ (9b) in lower yield which may be attributed to the slightly higher steric effect.

The reaction of $7 \mathbf{a}$ with $\mathrm{Me}_{3} \mathrm{SiCl}$ in $\mathrm{CH}_{2} \mathrm{Cl}_{2}$ did not yield the expected carbene complex, instead, the cationic vinylidene complex 8a-Cl was obtained. No nucleophilic reaction was observed between $\left\{\left(\mathrm{C}_{3} \mathrm{H}_{3} \mathrm{NNH}\right)[\mathrm{Ru}]=\mathrm{C}=\mathrm{C}(\mathrm{Ph})\right.$ $\left.\mathrm{CH}_{2} \mathrm{CN}\right\}^{+}$and $\mathrm{Cl}^{-}$possibly owing to weak nucleophilicity of the chloride. In addition, the corresponding reaction between $\mathrm{Me}_{3} \mathrm{SiCl}$ and $\mathbf{7 b}$ proceeded in a similar fashion to afford the cationic vinylidene complex $\left\{\left(\mathrm{Me}_{2} \mathrm{C}_{3} \mathrm{HNNH}\right)\right.$ $\left.[\mathrm{Ru}]=\mathrm{C}=\mathrm{C}(\mathrm{Ph}) \mathrm{CH}_{2} \mathrm{CN}\right\} \mathrm{Cl}(\mathbf{8 b}-\mathbf{C l})$ in lower yield. Similarly, treatment of $7 \mathbf{a}$ with $\mathrm{HgCl}_{2}$ affords the addition product $\left\{\left(\mathrm{C}_{3} \mathrm{H}_{3} \mathrm{NNH}\right)[\mathrm{Ru}=\mathrm{C}=\mathrm{C}(\mathrm{Ph}) \mathrm{CH}(\mathrm{HgCl}) \mathrm{CN}\} \mathrm{Cl} \quad(\mathbf{1 0 a})\right.$ and treatment of $7 \mathbf{b}$ with $\mathrm{HgCl}_{2}$ also gives $\left\{\left(\mathrm{Me}_{2} \mathrm{C}_{3^{-}}\right.\right.$ $\mathrm{HNNH})[\mathrm{Ru}]=\mathrm{C}=\mathrm{C}(\mathrm{Ph}) \mathrm{CH}(\mathrm{HgCl}) \mathrm{CN}\} \mathrm{Cl} \quad(\mathbf{1 0 b}) . \quad$ These 
reactions were carried out at $-20^{\circ} \mathrm{C}$ in $\mathrm{CH}_{2} \mathrm{Cl}_{2}$ since complex 10a and 10b are thermally unstable. However, upon dissolution at room temperature, complexes 10a and 10b immediately convert back to $\mathbf{7 a}$ and $\mathbf{7 b}$, respectively. Formation of these vinylidene complexes occurs by selective cleavage of the single $\mathrm{N}-\mathrm{C}_{\alpha}$ bond of the four-membered ring, which may have high ring strain.

\subsection{Reactions of $\mathbf{9 a}$ with electrophiles}

The reaction of 9a with $\mathrm{HCl}$ results in a protonation at the tetrazolate ring and gives $\mathbf{1 1}$ as the only product (Scheme 2). In the presence of excess $\mathrm{NH}_{4} \mathrm{PF}_{6}$ the counter anion is replaced by $\mathrm{PF}_{6}^{-}$. The ${ }^{1} \mathrm{H}$ NMR spectrum of $\mathbf{1 1}$ displays the characteristic pattern for the $\mathrm{CHCH}_{2}$ group. Two singlet ${ }^{31} \mathrm{P}$ NMR resonances at $\delta 53.7$ and 53.5 are assigned to the major and minor isomer, respectively. The protonation might have occurred at one of two nitrogen atoms next to the unique carbon of the tetrazolate ring because of localization of the negative charge at these two nitrogen atoms in 9a [14]. Similarly, preparation of the cationic tetrazolate complex $\left\{\left(\mathrm{C}_{3} \mathrm{H}_{3} \mathrm{NNH}\right)[\mathrm{Ru}]-\right.$ $\left.\mathrm{N}_{4}(\mathrm{R}) \mathrm{CCH}(\mathrm{Ph}) \mathrm{CH}_{2} \mathrm{CN}\right\}^{+} \quad\left(12 \mathrm{a}, \quad \mathrm{R}=\mathrm{CH}_{3}, \quad \mathbf{1 2 b}, \quad \mathrm{R}=\right.$ $\mathrm{C}_{6} \mathrm{H}_{5} \mathrm{CH}_{2}$ ) have all been accomplished by reacting $9 \mathbf{a}$ with the corresponding halides resulting in electrophilic addition with high yields. Complexes 11, 12a and 12b are all soluble in polar solvent such as $\mathrm{CHCl}_{3}, \mathrm{CH}_{2} \mathrm{Cl}_{2}, \mathrm{MeOH}$ and $\mathrm{MeCN}$ but insoluble in ether and hexane. These complexes all display green color in their solid state. The newly formed nitrogen-carbon bond of tetrazolate complexes 12a and 12b, prepared by carrying out the reaction at room temperature, is easily cleaved in the presence of acid. The hexafluorophosphate salt $\mathrm{NH}_{4} \mathrm{PF}_{6}$ used for the preparation is easily converted to $\mathrm{HPF}_{6}$. Complexes 11, 12a and 12b in solution are all stable for a period of 3 days and then decomposed to some unidentifiable products.

\subsection{Conclusions}

Reaction of the ruthenium complex $\mathbf{1}$ with $\mathrm{Me}_{3} \mathrm{SiN}_{3}$ afforded the N-coordinated nitrile complex 3 . Upon addition of $\mathrm{Me}_{3} \mathrm{SiN}_{3}$ to the neutral ruthenium cyclopropenyl complex $4 \mathrm{a}$ in the presence of $\mathrm{NH}_{4} \mathrm{PF}_{6}$ four nitrogens insert into the $\mathrm{Ru}-\mathrm{C}_{\alpha}$ to form the yellow zwitterionic tetrazolate complexes 6a. The reaction may proceed through the same type of intermediate as that in the formation of 3 from 1 followed by a further addition of $\mathrm{Me}_{3} \mathrm{SiN}_{3}$. Treatment of the ruthenium metallacyclic complex $7 \mathbf{a}$ with $\mathrm{Me}_{3} \mathrm{SiN}_{3}$ also gives the tetrazolate complex 9a but the reaction of $7 \mathbf{a}$ with $\mathrm{Me}_{3} \mathrm{SiCl}$ affords the cationic vinylidene complex 8a. Several new cationic tetrazolate complexes are prepared by electrophilic addition of organic halides to complex 9a. Characterization of these products has led to a better understanding on the chemical reactivity of the cyclopropenyl complexes. The reaction can be explained in terms of combined effects of the nucleophilic- ity of the $\mathrm{sp}^{3}$ carbon of the cyclopropenyl ring and the electrophilic nature of the $\mathrm{Me}_{3} \mathrm{Si}$ group.

\section{Experimental}

\subsection{Materials}

All manipulations were performed under nitrogen using vacuum-line, drybox, and standard Schlenk techniques. $\mathrm{CH}_{3} \mathrm{CN}$ and $\mathrm{CH}_{2} \mathrm{Cl}_{2}$ were distilled from $\mathrm{CaH}_{2}$ and diethyl ether and THF from Na/ketyl. All other solvents and reagents were of reagents grade and were used without further purification. NMR spectra were recorded on Bruker AC-200 and AM-300WB FT-NMR spectrometers at room temperature (unless stated otherwise) and are reported in unit $\delta$ with residual protons in the solvent as an internal standard $\left(\mathrm{CDCl}_{3}, \delta\right.$ 7.24; $\mathrm{CD}_{3} \mathrm{CN}, \delta 1.93 ; \mathrm{C}_{2} \mathrm{D}_{6} \mathrm{CO}, \delta$ 2.04). FAB mass spectra were recorded on a JEOL SX$102 \mathrm{~A}$ spectrometer. Elemental analyses were carried out at the Regional Center of Analytical Instrument at National Taiwan University. The complexes 1, 4a-e, 5a and $\mathbf{7 a}, \mathbf{b}$ were prepared according to literature methods $[6 \mathrm{c}]$.

\subsection{Synthesis of $\left\{\left(\mathrm{PPh}_{3}\right)[\mathrm{Ru}]=\mathrm{C}=\mathrm{C}(\mathrm{Ph}) \mathrm{CH}_{2} \mathrm{CN}\right\} \mathrm{N}_{3}$ (2)}

To a solution of complex $1(0.66 \mathrm{~g}, 0.67 \mathrm{mmol})$ in $20 \mathrm{~mL}$ $\mathrm{CH}_{2} \mathrm{Cl}_{2}$ at $0{ }^{\circ} \mathrm{C}$ was added $\mathrm{Me}_{3} \mathrm{SiN}_{3}(0.4 \mathrm{~mL}, 3.02 \mathrm{mmol})$. After $5 \mathrm{~h}$, the solution was slowly added to $90 \mathrm{~mL}$ of a diethyl ether solution. The green precipitate thus formed was filtered off and washed with diethyl ether and hexane to give a green product identified as $2(0.44 \mathrm{~g}, 64 \%$ yield $)$. Spectroscopic data for $2:{ }^{1} \mathrm{H}$ NMR $\left(\mathrm{CDCl}_{3}\right): \delta 7.89(\mathrm{br}$, 1H, Tp), 7.62 (br, 2H, Tp), 7.42-6.94 (m, $\mathrm{PPh}_{3}, \mathrm{C}_{2} \mathrm{Ph}$, $\mathrm{Ph}), 6.78$ (br, 1H, Tp), 6.66 (br, 1H, Tp), 5.73 (br, 2H, Tp), 5.60 (br, 1H, Tp), 5.47 (br, 1H, Tp). 3.08 (s, 2H, $\left.\mathrm{CH}_{2}\right) \cdot{ }^{13} \mathrm{C}$ NMR $\left(\mathrm{CDCl}_{3}\right): \delta 375.3\left(\mathrm{t}, J_{\mathrm{P}-\mathrm{C}}=16.5 \mathrm{~Hz}\right.$, $\left.\mathrm{C}_{\alpha}\right), 146.2-106.8\left(\mathrm{~m}, \mathrm{Ph}, \mathrm{Tp}, \mathrm{PPh}_{3}, \mathrm{C}_{\beta}\right), 117.4(\mathrm{CN}), 11.4$ $\left(\mathrm{CH}_{2}\right) \cdot{ }^{31} \mathrm{P}$ NMR $\left(\mathrm{CDCl}_{3}\right): \delta$ 36.5. MS (FAB) $\mathrm{m} / \mathrm{z}: 980.5$ $\left(\mathrm{M}^{+}-\mathrm{N}_{3}\right), 718.4\left(\mathrm{M}^{+}-\mathrm{N}_{3}, \mathrm{PPh}_{3}\right), 577.2\left(\mathrm{M}^{+}-\mathrm{N}_{3}, \mathrm{PPh}_{3}\right.$, $\mathrm{C}_{2} \mathrm{PhCH}_{2} \mathrm{CN}$ ). Anal. Calc. for $\mathrm{C}_{55} \mathrm{H}_{47} \mathrm{BN}_{10} \mathrm{P}_{2} \mathrm{Ru}$ (1022.3): C, 64.65; H, 4.64; N, 13.71. Found: C, 64.47; H, 4.69; N, $13.67 \%$.

\subsection{Synthesis of $\left\{\left(\mathrm{PPh}_{3}\right)[\mathrm{Ru}] \mathrm{NCCH}(\mathrm{Ph}) \mathrm{CH}_{2} \mathrm{CN}\right\} \mathrm{N}_{3}$ (3)}

To the solution of complex $1(0.66 \mathrm{~g}, 0.67 \mathrm{mmol})$ in $20 \mathrm{~mL} \mathrm{CH}_{2} \mathrm{Cl}_{2}$ at room temperature was added $\mathrm{Me}_{3} \mathrm{SiN}_{3}$ $(0.4 \mathrm{~mL}, 3.02 \mathrm{mmol})$. After $5 \mathrm{~h}$, the solution was slowly added to a $70 \mathrm{~mL}$ of diethyl ether solution. The light yellow precipitate thus formed was filtered off and washed with diethyl ether and hexane to give the product identified as $3(0.44 \mathrm{~g}, 63 \%$ yield). Spectroscopic data of 3: IR ( $\mathrm{KBr}$, $\left.\mathrm{cm}^{-1}\right): v(\mathrm{~B}-\mathrm{H}) 2465(\mathrm{br}), v(\mathrm{C} \equiv \mathrm{N}) 2253(\mathrm{~m}), 2243(\mathrm{w}) \mathrm{cm}^{-1}$. ${ }^{1} \mathrm{H}$ NMR $\left(\mathrm{CDCl}_{3}, \delta\right): \delta 7.58\left(\mathrm{~d}, J_{\mathrm{H}-\mathrm{H}}=2.1 \mathrm{~Hz}, 1 \mathrm{H}, \mathrm{Tp}\right)$, $7.40\left(\mathrm{~d}, J_{\mathrm{H}-\mathrm{H}}=2.0 \mathrm{~Hz}, 2 \mathrm{H}, \mathrm{Tp}\right), 7.24-6.91(\mathrm{~m}, \mathrm{Ph}, \mathrm{Tp})$, $5.54\left(\mathrm{t}, J_{\mathrm{H}-\mathrm{H}}=2.3 \mathrm{~Hz}, 2 \mathrm{H}, \mathrm{Tp}\right), 5.31\left(\mathrm{t}, J_{\mathrm{H}-\mathrm{H}}=2.1 \mathrm{~Hz}\right.$, 
$1 \mathrm{H}, \mathrm{Tp}), 5.20\left(\mathrm{~d}, J_{\mathrm{H}-\mathrm{H}}=1.8 \mathrm{~Hz}, 1 \mathrm{H}, \mathrm{Tp}\right), 4.11(\mathrm{dd}, 1 \mathrm{H}$, $\left.{ }^{3} J_{\mathrm{H}-\mathrm{H}}=6.7 \mathrm{~Hz},{ }^{3} J_{\mathrm{H}-\mathrm{H}}=7.0 \mathrm{~Hz}, \mathrm{CH}\right), 3.41\left(\mathrm{dd},{ }^{3} J_{\mathrm{H}-\mathrm{H}}=\right.$ $\left.6.7 \mathrm{~Hz},{ }^{3} J_{\mathrm{H}-\mathrm{H}}=7.0 \mathrm{~Hz}{ }^{2} J_{\mathrm{H}-\mathrm{H}}=16.9 \mathrm{~Hz}, 1 \mathrm{H}, \mathrm{CH}\right), 3.05$ $\left(\mathrm{dd},{ }^{3} J_{\mathrm{H}-\mathrm{H}}=6.7 \mathrm{~Hz}, \quad{ }^{3} J_{\mathrm{H}-\mathrm{H}}=7.0 \mathrm{~Hz},{ }^{2} J_{\mathrm{H}-\mathrm{H}}=16.7 \mathrm{~Hz}\right.$, $1 \mathrm{H}, \mathrm{CH}) .{ }^{13} \mathrm{C}$ NMR $\left(\mathrm{CDCl}_{3}\right): \delta 146.2-106.8(\mathrm{~m}, \mathrm{Ph}, \mathrm{Tp}$, $\left.\mathrm{PPh}_{3}\right), 117.4(\mathrm{CN}), 116.5\left(\mathrm{CH}_{2} \mathrm{CN}\right), 41.2(\mathrm{CH}), 39.1$ $\left(\mathrm{CH}_{2}\right) .{ }^{31} \mathrm{P}$ NMR $\left(\mathrm{CD}_{3} \mathrm{C}(\mathrm{O}) \mathrm{CD}_{3}, \mathrm{ppm}\right): \delta 39.1,38.7(\mathrm{AB}$, $\left.J_{\mathrm{P}-\mathrm{P}}=29.4 \mathrm{~Hz}\right) . \mathrm{MS}(\mathrm{FAB}) \mathrm{m} / z: 995.1\left(\mathrm{M}^{+}-\mathrm{N}_{3}\right), 733.4$ $\left(\mathrm{M}^{+}-\mathrm{N}_{3} \mathrm{PPh}_{3}\right), 577.1\left(\mathrm{M}^{+}-\mathrm{N}_{3}, \mathrm{PPh}_{3}, \mathrm{NCCH}(\mathrm{Ph}) \mathrm{CH}_{2} \mathrm{CN}\right)$. Anal. Calc. for $\mathrm{C}_{55} \mathrm{H}_{48} \mathrm{BN}_{11} \mathrm{P}_{2} \mathrm{Ru}$ (1037.3): $\mathrm{C}, 63.71 ; \mathrm{H}$, 4.67; N, 14.86. Found: C, 63.47; H, 4.55; N, 14.74\%.

\subsection{Synthesis of $\left(\mathrm{CH}_{3} \mathrm{CN}\right)[\mathrm{Ru}]-\mathrm{N}_{4} \mathrm{CH}(\mathrm{Ph}) \mathrm{CH}_{2} \mathrm{CN}(\boldsymbol{6 a})$}

To a solution of complex $4 \mathrm{a}(0.52 \mathrm{~g}, 0.69 \mathrm{mmol})$ in $30 \mathrm{~mL} \mathrm{CH}_{2} \mathrm{Cl}_{2}$ was added $\mathrm{Me}_{3} \mathrm{SiN}_{3}(0.4 \mathrm{~mL}, 3.02 \mathrm{mmol})$. After $24 \mathrm{~h}$, the solvent was removed under vacuum, then the solid residue was extracted with diethyl ether, and the extract was filtered. The resulting solution was removed under vacuum and washed with $5 \mathrm{~mL}$ hexane. The product was dried under vacuum. The bright yellow product was identified as $\mathbf{6 a}(0.30 \mathrm{~g}, 54 \%$ yield $)$. Spectroscopic data of 6a: IR $\left(\mathrm{KBr}, \mathrm{cm}^{-1}\right): v(\mathrm{~B}-\mathrm{H}) 2478(\mathrm{br}), v(\mathrm{C} \equiv \mathrm{N}) 2254(\mathrm{~m})$, $2241(\mathrm{w}), \quad v(\mathrm{~N}=\mathrm{N}) \quad 1436(\mathrm{w}) \quad \mathrm{cm}^{-1} .{ }^{1} \mathrm{H} \quad \mathrm{NMR} \quad\left(\mathrm{CD}_{3^{-}}\right.$ $\left.\mathrm{C}(\mathrm{O}) \mathrm{CD}_{3}\right)$ : major isomer: $\delta 7.65\left(\mathrm{~d}, J_{\mathrm{H}-\mathrm{H}}=2.1 \mathrm{~Hz}, 1 \mathrm{H}\right.$, $\mathrm{Tp}), 7.57\left(\mathrm{~d}, J_{\mathrm{H}-\mathrm{H}}=2.1 \mathrm{~Hz}, 1 \mathrm{H}, \mathrm{Tp}\right), 7.49\left(\mathrm{~d}, J_{\mathrm{H}-\mathrm{H}}=\right.$ $1.9 \mathrm{~Hz}, 1 \mathrm{H}, \mathrm{Tp}), 7.42-7.17(\mathrm{~m}, \mathrm{Ph}), 6.98(1 \mathrm{H}, \mathrm{Tp}), 6.78$ $(1 \mathrm{H}, \mathrm{Tp}), 6.76(1 \mathrm{H}, \mathrm{Tp}), 6.33\left(\mathrm{t}, J_{\mathrm{H}-\mathrm{H}}=2.1 \mathrm{~Hz}, 1 \mathrm{H}, \mathrm{Tp}\right)$, $5.98\left(\mathrm{t}, J_{\mathrm{H}-\mathrm{H}}=2.2 \mathrm{~Hz}, 1 \mathrm{H}, \mathrm{Tp}\right), 5.85\left(\mathrm{t}, J_{\mathrm{H}-\mathrm{H}}=2.2 \mathrm{~Hz}, 1 \mathrm{H}\right.$, $\mathrm{Tp}), 4.54\left(\mathrm{dd}, 1 \mathrm{H},{ }^{3} J_{\mathrm{H}-\mathrm{H}}=7.6 \mathrm{~Hz},{ }^{3} J_{\mathrm{H}-\mathrm{H}}=7.7 \mathrm{~Hz}, \mathrm{CH}\right)$, $3.19,2.94\left(\mathrm{dd}, \mathrm{AB},{ }^{3} J_{\mathrm{H}-\mathrm{H}}=7.6 \mathrm{~Hz},{ }^{3} J_{\mathrm{H}-\mathrm{H}}=7.7 \mathrm{~Hz}\right.$, $\left.{ }^{2} J_{\mathrm{H}-\mathrm{H}}=16.9 \mathrm{~Hz}, 2 \mathrm{H}, \mathrm{CH}_{2}\right), 2.22\left(\mathrm{~s}, 3 \mathrm{H}, \mathrm{CH}_{3} \mathrm{CN}\right)$; minor isomer: $\delta 7.65\left(\mathrm{~d}, J_{\mathrm{H}-\mathrm{H}}=2.1 \mathrm{~Hz}, 1 \mathrm{H}, \mathrm{Tp}\right), 7.57(\mathrm{~d}$, $\left.J_{\mathrm{H}-\mathrm{H}}=2.1 \mathrm{~Hz}, 1 \mathrm{H}, \mathrm{Tp}\right), 7.49\left(\mathrm{~d}, J_{\mathrm{H}-\mathrm{H}}=1.9 \mathrm{~Hz}, 1 \mathrm{H}, \mathrm{Tp}\right)$, 7.48-7.17 (m, Ph), $6.98(1 \mathrm{H}, \mathrm{Tp}), 6.78(1 \mathrm{H}, \mathrm{Tp}), 6.76$ $(1 \mathrm{H}, \mathrm{Tp}), 6.33\left(\mathrm{t}, J_{\mathrm{H}-\mathrm{H}}=2.1 \mathrm{~Hz}, 1 \mathrm{H}, \mathrm{Tp}\right), 5.98\left(\mathrm{t}, J_{\mathrm{H}-\mathrm{H}}=\right.$ $2.2 \mathrm{~Hz}, 1 \mathrm{H}, \mathrm{Tp}), 5.85\left(\mathrm{t}, J_{\mathrm{H}-\mathrm{H}}=2.2 \mathrm{~Hz}, 1 \mathrm{H}, \mathrm{Tp}\right), 4.49$ $\left(\mathrm{dd}, 1 \mathrm{H},{ }^{3} J_{\mathrm{H}-\mathrm{H}}=7.5 \mathrm{~Hz},{ }^{3} J_{\mathrm{H}-\mathrm{H}}=7.3 \mathrm{~Hz}, \mathrm{CH}\right), 3.02,2.76$ $\left(\mathrm{dd}, \quad \mathrm{AB}, \quad{ }^{3} J_{\mathrm{H}-\mathrm{H}}=7.5 \mathrm{~Hz}, \quad{ }^{3} J_{\mathrm{H}-\mathrm{H}}=7.3 \mathrm{~Hz},{ }^{2} J_{\mathrm{H}-\mathrm{H}}=\right.$ $\left.16.9 \mathrm{~Hz}, 2 \mathrm{H}, \mathrm{CH}_{2}\right), 2.27\left(\mathrm{~s}, 3 \mathrm{H}, \mathrm{CH}_{3} \mathrm{CN}\right) .{ }^{13} \mathrm{C} \mathrm{NMR}$ $\left(\mathrm{CDCl}_{3}\right)$ : major isomer: 146.9-105.6 (m, $\left.\mathrm{Ph}, \mathrm{PPh}_{3}, \mathrm{Tp}\right)$, $123.7\left(\mathrm{CH}_{3} \mathrm{CN}\right), 114.4(\mathrm{CN}), 38.4(\mathrm{CH}), 22.7\left(\mathrm{CH}_{2}\right), 3.6$ $\left(\mathrm{CH}_{3} \mathrm{CN}\right)$; minor isomer: 146.9-105.6 (m, $\left.\mathrm{Ph}, \mathrm{PPh}_{3}, \mathrm{Tp}\right)$, $124.1\left(\mathrm{CH}_{3} \mathrm{CN}\right), 115.3(\mathrm{CN}), 37.8(\mathrm{CH}), 21.9\left(\mathrm{CH}_{2}\right)$, $3.4\left(\mathrm{CH}_{3} \mathrm{CN}\right) .{ }^{31} \mathrm{P}$ NMR $\left(\mathrm{CD}_{3} \mathrm{C}(\mathrm{O}) \mathrm{CD}_{3}, \mathrm{ppm}\right): \delta 53.1$,

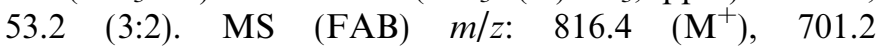
$\left(\mathrm{M}^{+}-\mathrm{N}_{4} \mathrm{CCH}(\mathrm{Ph}) \mathrm{CH}_{2} \mathrm{CN}\right), 577.1\left(\mathrm{M}^{+}-\mathrm{N}_{4} \mathrm{CCH}(\mathrm{Ph}) \mathrm{CH}_{2}-\right.$ $\mathrm{CN}, \mathrm{CH}_{3} \mathrm{CN}$ ). Anal. Calc. for $\mathrm{C}_{39} \mathrm{H}_{36} \mathrm{BN}_{12} \mathrm{PRu}$ (816.2): C, 57.43; H, 4.45; N, 20.61. Found: C, 57.27; H, 4.54; N, $20.48 \%$.

\subsection{Synthesis of $\left(p-\mathrm{CF}_{3} \mathrm{C}_{6} \mathrm{H}_{4} \mathrm{CN}\right)[\mathrm{Ru}]-\mathrm{N}_{4} \mathrm{CH}(\mathrm{Ph})-$ $\mathrm{CH}_{2} \mathrm{CN}(\mathbf{6} \boldsymbol{b})$}

To a solution of $\mathbf{4 b}(0.76 \mathrm{~g}, 0.86 \mathrm{mmol})$ in $20 \mathrm{~mL}$ of $\mathrm{CH}_{2} \mathrm{Cl}_{2}$ was added excess TMSN $3(0.6 \mathrm{~mL}, 4.5 \mathrm{mmol})$. After stirring for $20 \mathrm{~h}$, the solvent was removed under vac- uum, then the solid residue was extracted with diethyl ether, and the extract was filtered. The resulting solution was removed under vacuum and washed with $5 \mathrm{~mL}$ hexane. The product was dried under vacuum. The bright yellow product was identified as $\mathbf{6 b}(0.57 \mathrm{~g}, 69 \%$ yield $)$. Spectroscopic data of $\mathbf{6 b}$ : IR $\left(\mathrm{KBr}, \mathrm{cm}^{-1}\right): v(\mathrm{~B}-\mathrm{H}) 2497(\mathrm{br})$, $v(\mathrm{C} \equiv \mathrm{N}) \quad 2251(\mathrm{~m}), 2236(\mathrm{w}), \quad v(\mathrm{~N}=\mathrm{N}) \quad 1438(\mathrm{w}) \mathrm{cm}^{-1} \cdot{ }^{1} \mathrm{H}$ NMR $\left(\mathrm{CD}_{3} \mathrm{C}(\mathrm{O}) \mathrm{CD}_{3}\right)$ : major isomer: $\delta 7.81\left(\mathrm{~d}, J_{\mathrm{H}-\mathrm{H}}=\right.$ $2.1 \mathrm{~Hz}, 1 \mathrm{H}, \mathrm{Tp}), 7.80\left(\mathrm{~d}, J_{\mathrm{H}-\mathrm{H}}=2.2 \mathrm{~Hz}, 1 \mathrm{H}, \mathrm{Tp}\right), 7.69$ $\left(\mathrm{d}, J_{\mathrm{H}-\mathrm{H}}=2.0 \mathrm{~Hz}, 1 \mathrm{H}, \mathrm{Tp}\right), 7.40-7.07(\mathrm{~m}, \mathrm{Ph}), 6.86$ (br, 1H, Tp), $6.78(\mathrm{br}, 1 \mathrm{H}, \mathrm{Tp}), 6.76(\mathrm{br}, 1 \mathrm{H}, \mathrm{Tp}), 6.02(\mathrm{t}$, $\left.J_{\mathrm{H}-\mathrm{H}}=1.8 \mathrm{~Hz}, 1 \mathrm{H}, \mathrm{Tp}\right), 5.98\left(\mathrm{t}, J_{\mathrm{H}-\mathrm{H}}=2.1 \mathrm{~Hz}, 1 \mathrm{H}, \mathrm{Tp}\right)$, $5.85\left(\mathrm{t}, J_{\mathrm{H}-\mathrm{H}}=2.2 \mathrm{~Hz}, 1 \mathrm{H}, \mathrm{Tp}\right), 4.38\left(\mathrm{dd}, 1 \mathrm{H},{ }^{3} J_{\mathrm{H}-\mathrm{H}}=\right.$ $\left.7.6 \mathrm{~Hz}, \quad{ }^{3} J_{\mathrm{H}-\mathrm{H}}=7.7 \mathrm{~Hz}, \quad \mathrm{CH}\right), \quad 3.12, \quad 2.97(\mathrm{dd}, \quad \mathrm{AB}$, ${ }^{3} J_{\mathrm{H}-\mathrm{H}}=7.6 \mathrm{~Hz}, \quad{ }^{3} J_{\mathrm{H}-\mathrm{H}}=7.7 \mathrm{~Hz}, \quad{ }^{2} J_{\mathrm{H}-\mathrm{H}}=16.7 \mathrm{~Hz}, \quad 2 \mathrm{H}$, $\left.\mathrm{CH}_{2}\right)$; minor isomer: $\delta 7.81\left(\mathrm{~d}, J_{\mathrm{H}-\mathrm{H}}=2.1 \mathrm{~Hz}, 1 \mathrm{H}, \mathrm{Tp}\right)$, $7.80\left(\mathrm{~d}, J_{\mathrm{H}-\mathrm{H}}=2.2 \mathrm{~Hz}, 1 \mathrm{H}, \mathrm{Tp}\right), 7.69\left(\mathrm{~d}, J_{\mathrm{H}-\mathrm{H}}=2.0 \mathrm{~Hz}\right.$, 1H, Tp), 7.40-7.07 (m, Ph), 6.86 (br, 1H, Tp), 6.78 (br, $1 \mathrm{H}, \mathrm{Tp}), 6.76(\mathrm{br}, 1 \mathrm{H}, \mathrm{Tp}), 6.02\left(\mathrm{t}, J_{\mathrm{H}-\mathrm{H}}=1.8 \mathrm{~Hz}, 1 \mathrm{H}\right.$, $\mathrm{Tp}), 5.98\left(\mathrm{t}, J_{\mathrm{H}-\mathrm{H}}=2.1 \mathrm{~Hz}, 1 \mathrm{H}, \mathrm{Tp}\right), 5.85\left(\mathrm{t}, J_{\mathrm{H}-\mathrm{H}}=\right.$ $2.2 \mathrm{~Hz}, 1 \mathrm{H}, \mathrm{Tp}), 4.32\left(\mathrm{dd}, 1 \mathrm{H},{ }^{3} J_{\mathrm{H}-\mathrm{H}}=7.7 \mathrm{~Hz},{ }^{3} J_{\mathrm{H}-\mathrm{H}}=\right.$ $7.4 \mathrm{~Hz}, \quad \mathrm{CH}), \quad 3.21, \quad 2.87\left(\mathrm{dd}, \quad \mathrm{AB}, \quad{ }^{3} J_{\mathrm{H}-\mathrm{H}}=7.7 \mathrm{~Hz}\right.$, $\left.{ }^{3} J_{\mathrm{H}-\mathrm{H}}=7.4 \mathrm{~Hz},{ }^{2} J_{\mathrm{H}-\mathrm{H}}=16.9 \mathrm{~Hz}, 2 \mathrm{H}, \mathrm{CH}_{2},\right) \cdot{ }^{13} \mathrm{C} \mathrm{NMR}$ $\left(\mathrm{CD}_{3} \mathrm{C}(\mathrm{O}) \mathrm{CD}_{3}\right)$ major isomer: $\delta 148.2-126.6(\mathrm{~m}, \mathrm{Ph}, \mathrm{Tp})$, $118.1(\mathrm{CN}), 111.2(\mathrm{NCPh}), 110.6\left(\mathrm{q}, J_{\mathrm{F}-\mathrm{C}}=282.0 \mathrm{~Hz}\right.$, $\left.\mathrm{CF}_{3}\right), 40.3(\mathrm{CH}), 24.3\left(\mathrm{CH}_{2}\right)$; minor isomer: $\delta$ 147.7-125.1 $(\mathrm{m}, \mathrm{Ph}, \mathrm{Tp}), 118.5(\mathrm{CN}), 110.9(\mathrm{NCPh}), 109.8\left(\mathrm{q}, J_{\mathrm{F}-\mathrm{C}}=\right.$ $\left.279.0 \mathrm{~Hz}, \quad \mathrm{CF}_{3}\right), \quad 39.9(\mathrm{CH}), \quad 24.9\left(\mathrm{CH}_{2}\right) .{ }^{31} \mathrm{P} \quad \mathrm{NMR}$ $\left(\mathrm{CD}_{3} \mathrm{C}(\mathrm{O}) \mathrm{CD}_{3}\right): \delta 55.3,54.7$ (3: 2). MS (FAB) $\mathrm{m} / z: 946.4$ $\left(\mathrm{M}^{+}\right), 824.3\left(\mathrm{M}^{+}-\mathrm{N}_{4} \mathrm{CCH}(\mathrm{Ph}) \mathrm{CH}_{2} \mathrm{CN}\right), 577.1\left(\mathrm{M}^{+}-\mathrm{N}_{4^{-}}\right.$ $\left.\mathrm{CCH}(\mathrm{Ph}) \mathrm{CH}_{2} \mathrm{CN}, \quad \mathrm{CF}_{3} \mathrm{C}_{6} \mathrm{H}_{4} \mathrm{CN}\right)$. Anal. Calc. for $\mathrm{C}_{45} \mathrm{H}_{37} \mathrm{BF}_{3} \mathrm{~N}_{12} \mathrm{PRu}$ (946.2): C, 57.5; H, 3.94; N, 17.77. Found: C, 57.07; H, 4.04; N, 17.68\%.

\subsection{Synthesis of ( $\mathrm{PhCN})[\mathrm{Ru}]-\mathrm{N}_{4} \mathrm{CH}(\mathrm{Ph}) \mathrm{CH}_{2} \mathrm{CN}$ (6c)}

To a solution of $4 \mathbf{c}(1.17 \mathrm{~g}, 1.42 \mathrm{mmol})$ in $20 \mathrm{~mL}$ of $\mathrm{CH}_{2} \mathrm{Cl}_{2}$ was added excess TMSN $3(0.95 \mathrm{~mL}, 7.2 \mathrm{mmol})$. After stirring for $16 \mathrm{~h}$, the solvent was removed under vacuum, then the solid residue was extracted with diethyl ether, and the extract was filtered. The resulting solution was removed under vacuum and washed with $5 \mathrm{~mL}$ hexane. The product was dried under vacuum. The bright yellow product was identified as $\mathbf{6 c}(0.79 \mathrm{~g}, 63 \%$ yield $)$. Spectroscopic data of 6c: IR $\left(\mathrm{KBr}, \mathrm{cm}^{-1}\right): v(\mathrm{~B}-\mathrm{H}) 2481(\mathrm{br})$, $v(\mathrm{C} \equiv \mathrm{N}) 2257(\mathrm{~m}), 2238(\mathrm{w}), \quad v(\mathrm{~N}=\mathrm{N}) \quad 1432(\mathrm{w}) \mathrm{cm}^{-1} \cdot{ }^{1} \mathrm{H}$ NMR $\left(\mathrm{CD}_{3} \mathrm{C}(\mathrm{O}) \mathrm{CD}_{3}\right)$ major isomer: $\delta 7.91\left(\mathrm{~d}, J_{\mathrm{H}-\mathrm{H}}=\right.$ $2.2 \mathrm{~Hz}, 2 \mathrm{H}, \mathrm{Tp}), 7.69-7.03(\mathrm{~m}, \mathrm{Ph}), 6.97$ (br, 1H, Tp), $6.78(\mathrm{br}, 1 \mathrm{H}, \mathrm{Tp}), 6.06(\mathrm{br}, 1 \mathrm{H}, \mathrm{Tp}), 6.02\left(\mathrm{t}, J_{\mathrm{H}-\mathrm{H}}=\right.$ $2.1 \mathrm{~Hz}, 1 \mathrm{H}, \mathrm{Tp}), 5.90\left(\mathrm{t}, J_{\mathrm{H}-\mathrm{H}}=2.0 \mathrm{~Hz}, 1 \mathrm{H}, \mathrm{Tp}\right), 4.56$ $\left(\mathrm{dd}, 1 \mathrm{H},{ }^{3} J_{\mathrm{H}-\mathrm{H}}=7.9 \mathrm{~Hz},{ }^{3} J_{\mathrm{H}-\mathrm{H}}=7.4 \mathrm{~Hz}, \mathrm{CH}\right), 3.24,2.89$ $\left(\mathrm{dd}, \quad \mathrm{AB}, \quad{ }^{3} J_{\mathrm{H}-\mathrm{H}}=7.9 \mathrm{~Hz}, \quad{ }^{3} J_{\mathrm{H}-\mathrm{H}}=7.4 \mathrm{~Hz},{ }^{2} J_{\mathrm{H}-\mathrm{H}}=\right.$ $\left.16.7 \mathrm{~Hz}, 2 \mathrm{H}, \mathrm{CH}_{2,}\right)$; minor isomer: $\delta 7.91\left(\mathrm{~d}, J_{\mathrm{H}-\mathrm{H}}=\right.$ $2.2 \mathrm{~Hz}, 2 \mathrm{H}, \mathrm{Tp}), 7.69-7.03(\mathrm{~m}, \mathrm{Ph}), 6.97$ (br, 1H, Tp), $6.78(\mathrm{br}, 1 \mathrm{H}, \mathrm{Tp}), 6.06(\mathrm{br}, 1 \mathrm{H}, \mathrm{Tp}), 6.02\left(\mathrm{t}, J_{\mathrm{H}-\mathrm{H}}=\right.$ $2.1 \mathrm{~Hz}, 1 \mathrm{H}, \mathrm{Tp}), 5.90\left(\mathrm{t}, J_{\mathrm{H}-\mathrm{H}}=2.0 \mathrm{~Hz}, 1 \mathrm{H}, \mathrm{Tp}\right), 4.41$ $\left(\mathrm{dd}, 1 \mathrm{H},{ }^{3} J_{\mathrm{H}-\mathrm{H}}=7.7 \mathrm{~Hz},{ }^{3} J_{\mathrm{H}-\mathrm{H}}=7.3 \mathrm{~Hz}, \mathrm{CH}\right), 3.19,2.74$ 
$\left(\mathrm{dd}, \mathrm{AB},{ }^{3} J_{\mathrm{H}-\mathrm{H}}=7.7 \mathrm{~Hz},{ }^{3} J_{\mathrm{H}-\mathrm{H}}=7.3 \mathrm{~Hz},{ }^{2} J_{\mathrm{H}-\mathrm{H}}=16.7\right.$ $\left.\mathrm{Hz}, 2 \mathrm{H}, \mathrm{CH}_{2},\right) \cdot{ }^{13} \mathrm{C}$ NMR $\left(\mathrm{CD}_{3} \mathrm{C}(\mathrm{O}) \mathrm{CD}_{3}\right)$ major isomer: $\delta 149.3-121.3(\mathrm{~m}, \mathrm{Ph}, \mathrm{Tp}), 118.1(\mathrm{CN}), 115.3(\mathrm{NCPh})$, $39.1(\mathrm{CH}), 23.9\left(\mathrm{CH}_{2}\right)$; minor isomer: $\delta$ 149.8-122.4 (m, $\mathrm{Ph}, \mathrm{Tp}), 118.9(\mathrm{CN}), 116.3(\mathrm{NCPh}), 39.7(\mathrm{CH}), 23.0$ $\left(\mathrm{CH}_{2}\right) .{ }^{31} \mathrm{P}$ NMR $\left(\mathrm{CDCCl}_{3}, \mathrm{ppm}\right): \delta 55.7,55.6(3: 2) . \mathrm{MS}$ (FAB) $\quad m / z: \quad 878.3 \quad\left(\mathrm{M}^{+}\right), \quad 680.2 \quad\left(\mathrm{M}^{+}-\mathrm{N}_{4} \mathrm{CCH}(\mathrm{Ph})-\right.$ $\left.\mathrm{CH}_{2} \mathrm{CN}\right), 577.1\left(\mathrm{M}^{+}-\mathrm{N}_{4} \mathrm{CCH}(\mathrm{Ph}) \mathrm{CH}_{2} \mathrm{CN}, \mathrm{PhCN}\right)$. Anal. Calc. for $\mathrm{C}_{44} \mathrm{H}_{38} \mathrm{BN}_{12} \mathrm{PRu}$ (877.7): C, 60.21; $\mathrm{H}, 4.36$; N, 19.15. Found: C, 59.97; H, 4.36; N, 18.98\%.

\subsection{Synthesis of $(t-B u N C)[R u]-\mathrm{N}_{4} \mathrm{CH}(\mathrm{Ph}) \mathrm{CH}_{2} \mathrm{CN}$ (6d)}

A mixture of complex $4 \mathbf{d}(0.58 \mathrm{~g}, 0.73 \mathrm{mmol})$ and $\mathrm{Me}_{3} \mathrm{SiN}_{3}(0.24 \mathrm{~mL}, 1.52 \mathrm{mmol})$ in $20 \mathrm{~mL}$ of $\mathrm{CH}_{2} \mathrm{Cl}_{2} /$ $\mathrm{CH}_{3} \mathrm{Cl}$ (3:1) was heated to reflux for $20 \mathrm{~h}$. The solvent was removed under vacuum, then the solid residue was extracted with diethyl ether, and the extract was filtered. The resulting solution was removed under vacuum and washed with $5 \mathrm{~mL}$ hexane. The product was dried under vacuum. The yellow product was identified as $6 \mathbf{d}(0.40 \mathrm{~g}$, $64 \%$ yield). Spectroscopic data of $\mathbf{6 d}$ : IR $\left(\mathrm{KBr}, \mathrm{cm}^{-1}\right)$ : $v(\mathrm{~B}-\mathrm{H}) \quad 2468(\mathrm{br}), \quad v(\mathrm{C} \equiv \mathrm{N}) \quad 2232(\mathrm{w}), \quad v(\mathrm{~N} \equiv \mathrm{C}) \quad 2135(\mathrm{~s})$, $v(\mathrm{~N}=\mathrm{N}) 1436(\mathrm{w}) \mathrm{cm}^{-1} \cdot{ }^{1} \mathrm{H}$ NMR $\left(\mathrm{CD}_{3} \mathrm{C}(\mathrm{O}) \mathrm{CD}_{3}\right)$ : major isomer: $\delta 7.81\left(\mathrm{~d}, J_{\mathrm{H}-\mathrm{H}}=2.1 \mathrm{~Hz}, 1 \mathrm{H}, \mathrm{Tp}\right), 7.82(\mathrm{~d}$, $\left.J_{\mathrm{H}-\mathrm{H}}=2.0 \mathrm{~Hz}, 1 \mathrm{H}, \mathrm{Tp}\right), 7.71\left(\mathrm{~d}, J_{\mathrm{H}-\mathrm{H}}=1.9 \mathrm{~Hz}, 1 \mathrm{H}, \mathrm{Tp}\right)$, 7.67-7.11 (m, Ph), $6.65(\mathrm{~m}, 1 \mathrm{H}, \mathrm{Tp}), 6.11(\mathrm{br}, 1 \mathrm{H}, \mathrm{Tp})$, $6.04(\mathrm{br}, 1 \mathrm{H}, \mathrm{Tp}), 5.92\left(\mathrm{t}, J_{\mathrm{H}-\mathrm{H}}=1.9 \mathrm{~Hz}, 1 \mathrm{H}, \mathrm{Tp}\right), 5.89$ $\left(\mathrm{t}, J_{\mathrm{H}-\mathrm{H}}=2.1 \mathrm{~Hz}, 1 \mathrm{H}, \mathrm{Tp}\right), 5.81\left(\mathrm{t}, J_{\mathrm{H}-\mathrm{H}}=2.1 \mathrm{~Hz}, 1 \mathrm{H}\right.$, $\mathrm{Tp}), 4.34\left(\mathrm{dd}, 1 \mathrm{H},{ }^{3} J_{\mathrm{H}-\mathrm{H}}=7.2 \mathrm{~Hz},{ }^{3} J_{\mathrm{H}-\mathrm{H}}=7.2 \mathrm{~Hz}, \mathrm{CH}\right)$, $3.11,2.92\left(\mathrm{dd}, \mathrm{AB},{ }^{3} J_{\mathrm{H}-\mathrm{H}}=7.2 \mathrm{~Hz},{ }^{3} J_{\mathrm{H}-\mathrm{H}}=7.2 \mathrm{~Hz}\right.$, $\left.{ }^{2} J_{\mathrm{H}-\mathrm{H}}=16.9 \mathrm{~Hz}, 2 \mathrm{H}, \mathrm{CH}_{2},\right), 1.42(\mathrm{~s}, 9 \mathrm{H}, \mathrm{Me})$; minor isomer: $\delta 7.81\left(\mathrm{~d}, J_{\mathrm{H}-\mathrm{H}}=2.1 \mathrm{~Hz}, 1 \mathrm{H}, \mathrm{Tp}\right), 7.82\left(\mathrm{~d}, J_{\mathrm{H}-\mathrm{H}}=\right.$ $2.0 \mathrm{~Hz}, 1 \mathrm{H}, \mathrm{Tp}), 7.71\left(\mathrm{~d}, J_{\mathrm{H}-\mathrm{H}}=1.9 \mathrm{~Hz}, 1 \mathrm{H}, \mathrm{Tp}\right), 7.67-$ $7.11(\mathrm{~m}, \mathrm{Ph}), 6.65(\mathrm{~m}, 1 \mathrm{H}, \mathrm{Tp}), 6.11(\mathrm{br}, 1 \mathrm{H}, \mathrm{Tp}), 6.04$ (br, $1 \mathrm{H}, \mathrm{Tp}), 5.92\left(\mathrm{t}, J_{\mathrm{H}-\mathrm{H}}=1.9 \mathrm{~Hz}, 1 \mathrm{H}, \mathrm{Tp}\right), 5.89(\mathrm{t}$, $\left.J_{\mathrm{H}-\mathrm{H}}=2.1 \mathrm{~Hz}, 1 \mathrm{H}, \mathrm{Tp}\right), 5.81\left(\mathrm{t}, J_{\mathrm{H}-\mathrm{H}}=2.1 \mathrm{~Hz}, 1 \mathrm{H}, \mathrm{Tp}\right)$, $4.34\left(\mathrm{dd}, 1 \mathrm{H},{ }^{3} J_{\mathrm{H}-\mathrm{H}}=7.2 \mathrm{~Hz},{ }^{3} J_{\mathrm{H}-\mathrm{H}}=7.2 \mathrm{~Hz}, \mathrm{CH}\right), 3.21$, $2.98\left(\mathrm{dd}, \mathrm{AB},{ }^{3} J_{\mathrm{H}-\mathrm{H}}=7.2 \mathrm{~Hz},{ }^{3} J_{\mathrm{H}-\mathrm{H}}=7.2 \mathrm{~Hz},{ }^{2} J_{\mathrm{H}-\mathrm{H}}=\right.$ $\left.16.1 \mathrm{~Hz}, 2 \mathrm{H}, \quad \mathrm{CH}_{2}\right), \quad 1.32(\mathrm{~s}, \quad 9 \mathrm{H}, \mathrm{Me}) .{ }^{13} \mathrm{C} \quad \mathrm{NMR}$ $\left(\mathrm{CD}_{3} \mathrm{C}(\mathrm{O}) \mathrm{CD}_{3}\right)$ major isomer: $\delta 163.4\left(\mathrm{~d}, J_{\mathrm{P}-\mathrm{C}}=21.4 \mathrm{~Hz}\right.$, CNC(Me) $\left.)_{3}\right), 141.9-129.3$ (m, Ph, Tp), $119.4(\mathrm{CN}), 58.7$ $\left(\mathrm{CNCMe}_{3}\right), 32.1\left(\mathrm{CNCMe}_{3}\right), 39.8(\mathrm{CH}), 24.2\left(\mathrm{CH}_{2}\right)$; minor isomer: $\delta 167.8\left(\mathrm{~d}, J_{\mathrm{P}-\mathrm{C}}=22.1 \mathrm{~Hz}, C \mathrm{NC}(\mathrm{Me})_{3}\right), 145.1-$ $125.6(\mathrm{~m}, \mathrm{Ph}, \mathrm{Tp}), 118.1(\mathrm{CN}), 57.8\left(\mathrm{CNCMe}_{3}\right), 31.9$ $\left(\mathrm{CNCMe}_{3}\right), 39.9(\mathrm{CH}), 25.6\left(\mathrm{CH}_{2}\right) .{ }^{31} \mathrm{P}$ NMR $\left(\mathrm{CDCCl}_{3}\right.$, ppm): $\delta 54.1,54.7$ (3:2). MS (FAB) $m / z: 858.4\left(\mathrm{M}^{+}\right)$, $660.2 \quad\left(\mathrm{M}^{+}-\mathrm{N}_{4} \mathrm{CCH}(\mathrm{Ph}) \mathrm{CH}_{2} \mathrm{CN}\right), \quad 577.1 \quad\left(\mathrm{M}^{+}-\mathrm{N}_{4^{-}}\right.$ $\mathrm{CCH}(\mathrm{Ph}) \mathrm{CH}_{2} \mathrm{CN}, t$-BuNC). Anal. Calc. for $\mathrm{C}_{42} \mathrm{H}_{42^{-}}$ $\mathrm{BN}_{12} \mathrm{PRu}$ (858.3): C, 58.81; H, 4.94; N, 19.60. Found: C, $58.91 ; \mathrm{H}, 5.14 ; \mathrm{N}, 19.37 \%$.

\subsection{Synthesis of (n-BuNC)[Ru]- $\mathrm{N}_{4} \mathrm{CH}(\mathrm{Ph}) \mathrm{CH}_{2} \mathrm{CN}$ (6e)}

Solution of complex $4 \mathbf{e}(0.20 \mathrm{~g}, 0.25 \mathrm{mmol})$ in $20 \mathrm{~mL}$ $\mathrm{CH}_{2} \mathrm{Cl}_{2}$ was added $\mathrm{Me}_{3} \mathrm{SiN}_{3}(0.16 \mathrm{~mL}, 0.76 \mathrm{mmol})$. After stirring for $16 \mathrm{~h}$, the solvent was removed under vacuum, then the solid residue was extracted with diethyl ether, and the extract was filtered. The resulting solution was removed under vacuum and washed with $5 \mathrm{~mL}$ hexane. The product was dried under vacuum. The bright yellow product was identified as $6 \mathrm{6e}(0.19 \mathrm{~g}, 89 \%$ yield $)$. Spectroscopic data of 6e: IR $\left(\mathrm{KBr}, \mathrm{cm}^{-1}\right): v(\mathrm{~B}-\mathrm{H})$ 2475(br), $v(\mathrm{C} \equiv \mathrm{N}) \quad 2233(\mathrm{w}), \quad v(\mathrm{~N} \equiv \mathrm{C}) \quad 2141(\mathrm{~s}), \quad v(\mathrm{~N}=\mathrm{N}) \quad 1436(\mathrm{w})$ $\mathrm{cm}^{-1}$. ${ }^{1} \mathrm{H}$ NMR $\left(\mathrm{CD}_{3} \mathrm{C}(\mathrm{O}) \mathrm{CD}_{3}\right)$ major isomer: $\delta 7.57(\mathrm{~d}$, $\left.J_{\mathrm{H}-\mathrm{H}}=2.0 \mathrm{~Hz}, 1 \mathrm{H}, \mathrm{Tp}\right), 7.79\left(\mathrm{~d}, J_{\mathrm{H}-\mathrm{H}}=2.1 \mathrm{~Hz}, 1 \mathrm{H}, \mathrm{Tp}\right)$, $7.71\left(\mathrm{~d}, J_{\mathrm{H}-\mathrm{H}}=2.0 \mathrm{~Hz}, 1 \mathrm{H}, \mathrm{Tp}\right), 7.40-6.91(\mathrm{~m}, \mathrm{Ph}), 6.86$ (m, 1H, Tp), $6.74(\mathrm{br}, 1 \mathrm{H}, \mathrm{Tp}), 6.71(\mathrm{br}, 1 \mathrm{H}, \mathrm{Tp}), 5.92(\mathrm{t}$, $\left.J_{\mathrm{H}-\mathrm{H}}=1.9 \mathrm{~Hz}, 1 \mathrm{H}, \mathrm{Tp}\right), 5.88\left(\mathrm{t}, J_{\mathrm{H}-\mathrm{H}}=2.0 \mathrm{~Hz}, 1 \mathrm{H}, \mathrm{Tp}\right)$, $5.76\left(\mathrm{t}, J_{\mathrm{H}-\mathrm{H}}=2.1 \mathrm{~Hz}, 1 \mathrm{H}, \mathrm{Tp}\right), 4.43\left(\mathrm{dd}, 1 \mathrm{H},{ }^{3} J_{\mathrm{H}-\mathrm{H}}=\right.$ $\left.7.3 \mathrm{~Hz},{ }^{3} J_{\mathrm{H}-\mathrm{H}}=7.2 \mathrm{~Hz}, \mathrm{CH}\right), 3.69\left(\mathrm{t}, J_{\mathrm{H}-\mathrm{H}}=6.6 \mathrm{~Hz}, 2 \mathrm{H}\right.$, $\left.\mathrm{CNCH}_{2} \mathrm{CH}_{2}\right), \quad 3.21, \quad 2.76\left(\mathrm{dd}, \quad \mathrm{AB},{ }^{3} \mathrm{~J}_{\mathrm{H}-\mathrm{H}}=7.3 \mathrm{~Hz}\right.$, $\left.{ }^{3} J_{\mathrm{H}-\mathrm{H}}=7.2 \mathrm{~Hz},{ }^{2} J_{\mathrm{H}-\mathrm{H}}=16.7 \mathrm{~Hz}, 2 \mathrm{H}, \mathrm{CH}_{2}\right), 1.53(\mathrm{~m}$, $\left.2 \mathrm{H}, \mathrm{CNCH}_{2} \mathrm{CH}_{2}\right), 1.23\left(\mathrm{~m}, 2 \mathrm{H}, \mathrm{CH}_{2} \mathrm{CH}_{3}\right), 0.93(\mathrm{~s}, 1 \mathrm{H}$, $\mathrm{C}_{2} \mathrm{PhCHCN}$ ), 0.75 ( $\mathrm{t}, J_{\mathrm{H}-\mathrm{H}}=7.5 \mathrm{~Hz}, 3 \mathrm{H}, \mathrm{CH}_{3}$ ); minor isomer: $\delta 7.57\left(\mathrm{~d}, J_{\mathrm{H}-\mathrm{H}}=2.0 \mathrm{~Hz}, 1 \mathrm{H}, \mathrm{Tp}\right), 7.79\left(\mathrm{~d}, J_{\mathrm{H}-\mathrm{H}}=\right.$ $2.1 \mathrm{~Hz}, 1 \mathrm{H}, \mathrm{Tp}), 7.71\left(\mathrm{~d}, J_{\mathrm{H}-\mathrm{H}}=2.0 \mathrm{~Hz}, 1 \mathrm{H}, \mathrm{Tp}\right), 7.40$ $6.91(\mathrm{~m}, \mathrm{Ph}), 6.86(\mathrm{~m}, 1 \mathrm{H}, \mathrm{Tp}), 6.74(\mathrm{br}, 1 \mathrm{H}, \mathrm{Tp}), 6.71$ (br, $1 \mathrm{H}, \mathrm{Tp}), 5.92\left(\mathrm{t}, J_{\mathrm{H}-\mathrm{H}}=1.9 \mathrm{~Hz}, 1 \mathrm{H}, \mathrm{Tp}\right), 5.88(\mathrm{t}$, $\left.J_{\mathrm{H}-\mathrm{H}}=2.0 \mathrm{~Hz}, 1 \mathrm{H}, \mathrm{Tp}\right), 5.76\left(\mathrm{t}, J_{\mathrm{H}-\mathrm{H}}=2.1 \mathrm{~Hz}, 1 \mathrm{H}, \mathrm{Tp}\right)$, $4.47\left(\mathrm{dd}, 1 \mathrm{H},{ }^{3} J_{\mathrm{H}-\mathrm{H}}=7.1 \mathrm{~Hz},{ }^{3} J_{\mathrm{H}-\mathrm{H}}=7.3 \mathrm{~Hz}, \mathrm{CH}\right), 3.54$ $\left(\mathrm{t}, J_{\mathrm{H}-\mathrm{H}}=6.7 \mathrm{~Hz}, 2 \mathrm{H}, \mathrm{CNCH}_{2} \mathrm{CH}_{2}\right), 3.01,2.89(\mathrm{dd}, \mathrm{AB}$, ${ }^{3} J_{\mathrm{H}-\mathrm{H}}=7.1 \mathrm{~Hz}, \quad{ }^{3} J_{\mathrm{H}-\mathrm{H}}=7.3 \mathrm{~Hz},{ }^{2} J_{\mathrm{H}-\mathrm{H}}=16.1 \mathrm{~Hz}, \quad 2 \mathrm{H}$, $\mathrm{CH}_{2}$ ), $1.63\left(\mathrm{~m}, 2 \mathrm{H}, \mathrm{CNCH}_{2} \mathrm{CH}_{2}\right), 1.10\left(\mathrm{~m}, 2 \mathrm{H}, \mathrm{CH}_{2} \mathrm{CH}_{3}\right)$, $0.91\left(\mathrm{~s}, 1 \mathrm{H}, \mathrm{C}_{2} \mathrm{PhCHCN}\right), 0.71\left(\mathrm{t}, J_{\mathrm{H}-\mathrm{H}}=7.4 \mathrm{~Hz}, 3 \mathrm{H}\right.$, $\left.\mathrm{CH}_{3}\right) \cdot{ }^{13} \mathrm{C}$ NMR $\left(\mathrm{CD}_{3} \mathrm{C}(\mathrm{O}) \mathrm{CD}_{3}\right)$ major isomer: $\delta 162.4$ $\left(\mathrm{d}, J_{\mathrm{P}-\mathrm{C}}=22.9 \mathrm{~Hz}, \mathrm{CNCH}_{2} \mathrm{CH}_{2}\right), 143.6-126.9$ (m, Ph, $\mathrm{Tp}), 125.9\left(\mathrm{~d}, J_{\mathrm{P}-\mathrm{C}}=11.6 \mathrm{~Hz}, \mathrm{C} \alpha\right), 114.9(\mathrm{CN}), 43.6$ $\left(\mathrm{CNCH}_{2} \mathrm{CH}_{2}\right), 33.7\left(\mathrm{CNCH}_{2} \mathrm{CH}_{2}\right), 21.5\left(\mathrm{CH}_{2} \mathrm{CH}_{3}\right), 13.8$ $\left(\mathrm{CH}_{2} \mathrm{CH}_{3}\right), 37.9(\mathrm{CH}), 25.1\left(\mathrm{CH}_{2}\right)$; minor isomer: $\delta 165.1$ $\left(\mathrm{d}, J_{\mathrm{P}-\mathrm{C}}=22.5 \mathrm{~Hz}, C \mathrm{NCH}_{2} \mathrm{CH}_{2}\right), 145.1-128.9(\mathrm{~m}, \mathrm{Ph}$, $\mathrm{Tp}), 127.8\left(\mathrm{~d}, J_{\mathrm{P}-\mathrm{C}}=11.7 \mathrm{~Hz}, \mathrm{C} \alpha\right), 114.8(\mathrm{CN}), 44.1$ $\left(\mathrm{CNCH}_{2} \mathrm{CH}_{2}\right), 32.5\left(\mathrm{CNCH}_{2} \mathrm{CH}_{2}\right), 20.9\left(\mathrm{CH}_{2} \mathrm{CH}_{3}\right), 13.1$

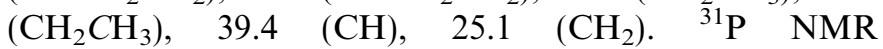
$\left(\mathrm{CD}_{3} \mathrm{C}(\mathrm{O}) \mathrm{CD}_{3}\right): \delta$ 54.1, $53.9(3: 2)$. MS (FAB) $\mathrm{m} / z: 858.4$ $\left(\mathrm{M}^{+}\right), \quad 660.2 \quad\left(\mathrm{M}^{+}-\mathrm{N}_{4} \mathrm{CCH}(\mathrm{Ph}) \mathrm{CH}_{2} \mathrm{CN}\right), \quad 577.1$ $\left(\mathrm{M}^{+}-\mathrm{N}_{4} \mathrm{CCH}(\mathrm{Ph}) \mathrm{CH}_{2} \mathrm{CN}, n\right.$-BuNC). Anal. Calc. for $\mathrm{C}_{42} \mathrm{H}_{42} \mathrm{BN}_{12} \mathrm{PRu}$ (858.3): C, 58.81; H, 4.94; N, 19.60 . Found: C, 58.67; H, 5.04; N, 19.48\%.

\subsection{Synthesis of $\left\{\left(\mathrm{C}_{3} \mathrm{H}_{3} \mathrm{NNH}\right)[\mathrm{Ru}]=C=C(\mathrm{Ph})\right.$ - $\left.\mathrm{CH}_{2} \mathrm{CN}\right\} \mathrm{Cl}(\boldsymbol{8 a}-\mathrm{Cl})$}

Solution of complex 7a $(10 \mathrm{mg}, 0.013 \mathrm{mmol})$ in $\mathrm{CD}_{3} \mathrm{C}(\mathrm{O}) \mathrm{CD}_{3}$ prepared under $\mathrm{N}_{2}$ in NMR tube, one drop $(5 \mu \mathrm{L})$ of $\left(\mathrm{CH}_{3}\right)_{3} \mathrm{SiCl}$ was added. The reaction accomplished immediately, and the color changed fro bright yellow to green. The solvent was removed under vacuum and washed with hexane. The green product was identified as 8a-Cl. Spectroscopic data of $\mathbf{8 a}-\mathbf{C l}:{ }^{1} \mathrm{H}$ NMR $\left(\mathrm{CD}_{3} \mathrm{C}(\mathrm{O}) \mathrm{CD}_{3}\right): \delta 12.58(\mathrm{~s}, \mathrm{NH}), 8.13\left(\mathrm{~d}, J_{\mathrm{H}-\mathrm{H}}=2.2 \mathrm{~Hz}\right.$, $1 \mathrm{H}, \mathrm{Tp}), 8.04\left(\mathrm{~d}, J_{\mathrm{H}-\mathrm{H}}=2.4 \mathrm{~Hz}, 1 \mathrm{H}, \mathrm{Tp}\right), 7.70-6.58(\mathrm{~m}$, $\mathrm{Ph}, \mathrm{Tp}), 6.53\left(\mathrm{~d}, J_{\mathrm{H}-\mathrm{H}}=2.1 \mathrm{~Hz}, 1 \mathrm{H}, \mathrm{Tp}\right), 6.44\left(\mathrm{~d}, J_{\mathrm{H}-\mathrm{H}}=\right.$ $2.3 \mathrm{~Hz}, \mathrm{Tp}), 6.17(\mathrm{~m}, 2 \mathrm{H}, \mathrm{Tp}), 5.96\left(\mathrm{~d}, J_{\mathrm{H}-\mathrm{H}}=2.3 \mathrm{~Hz}\right.$, 
$1 \mathrm{H}, \mathrm{Tp}), 3.94\left(\mathrm{~d}, J_{\mathrm{H}-\mathrm{H}}=17.9 \mathrm{~Hz}, 1 \mathrm{H}, \mathrm{C}_{2} \mathrm{PhCH} H \mathrm{CN}\right), 3.84$ $\left(\mathrm{d}, \quad J_{\mathrm{H}-\mathrm{H}}=17.9 \mathrm{~Hz}, \quad 1 \mathrm{H}, \quad \mathrm{C}_{2} \mathrm{PhCH} H \mathrm{CN}\right) .{ }^{13} \mathrm{C} \quad \mathrm{NMR}$ $\left(\mathrm{CD}_{3} \mathrm{C}(\mathrm{O}) \mathrm{CD}_{3}\right): \delta 375.3\left(\mathrm{~d}, J_{\mathrm{P}-\mathrm{C}}=16.5 \mathrm{~Hz}, \mathrm{C}_{\alpha}\right), 151.6-$ $129.4\left(\mathrm{Ph}, \mathrm{PPh}_{3}, \mathrm{Tp}\right), 117.4(\mathrm{CN}), 16.7\left(\mathrm{CH}_{2}\right) .{ }^{31} \mathrm{P}$ NMR $\left(\mathrm{CD}_{3} \mathrm{C}(\mathrm{O}) \mathrm{CD}_{3}\right): \delta$ 35.2. MS (FAB) $m / z: 786.3\left(\mathrm{M}^{+}-\mathrm{Cl}\right)$, $718.3\left(\mathrm{M}^{+}-\mathrm{Cl}, \quad \mathrm{NCHCHCHNH}\right), \quad 577.1 \quad\left(\mathrm{M}^{+}-\mathrm{Cl}\right.$, $\mathrm{NCHCHCHNH}, \mathrm{C}_{2} \mathrm{PhCH}_{2} \mathrm{CN}$ ). Anal. Calc. for $\mathrm{C}_{40} \mathrm{H}_{36^{-}}$ $\mathrm{BClN}_{9} \mathrm{PRu}$ (822.1): C, 58.51; H, 4.42; N, 15.35. Found: C, 58.47; H, 4.64; N, 15.48\%.

\subsection{Synthesis of $\left\{\left(\mathrm{Me}_{2} \mathrm{C}_{3} \mathrm{HNNH}\right)[\mathrm{Ru}]=C=C(\mathrm{Ph})\right.$ - $\left.\mathrm{CH}_{2} \mathrm{CN}\right\} \mathrm{Cl}(\boldsymbol{8 b}-\mathrm{Cl})$}

Solution of complex $7 \mathbf{b} \quad(16 \mathrm{mg}, \quad 0.015 \mathrm{mmol})$ in $\mathrm{CD}_{3} \mathrm{C}(\mathrm{O}) \mathrm{CD}_{3}$ prepared under $\mathrm{N}_{2}$ in NMR tube, one drop $(5 \mu \mathrm{L})$ of $\left(\mathrm{CH}_{3}\right)_{3} \mathrm{SiCl}$ was added. The reaction accomplished immediately, and the color changed fro bright yellow to green. The solvent was removed under vacuum and washed with hexane. The green product was identified as 8b-Cl. Spectroscopic data of $\mathbf{8 b}-\mathbf{C l}:{ }^{1} \mathrm{H} \quad \mathrm{NMR}$ $\left(\mathrm{CD}_{3} \mathrm{C}(\mathrm{O}) \mathrm{CD}_{3}\right): \delta 12.67(\mathrm{~s}, \mathrm{NH}), 8.10\left(\mathrm{~d}, J_{\mathrm{H}-\mathrm{H}}=2.2 \mathrm{~Hz}\right.$, $1 \mathrm{H}, \mathrm{Tp}), 8.04\left(\mathrm{t}, J_{\mathrm{H}-\mathrm{H}}=2.4 \mathrm{~Hz}, 2 \mathrm{H}, \mathrm{Tp}\right), 7.94(\mathrm{br}, 1 \mathrm{H})$, 7.69-6.82 (m, Ph, Tp), $6.41\left(\mathrm{~d}, J_{\mathrm{H}-\mathrm{H}}=2.1 \mathrm{~Hz}, 1 \mathrm{H}, \mathrm{Tp}\right)$, $6.29\left(\mathrm{~d}, J_{\mathrm{H}-\mathrm{H}}=2.3 \mathrm{~Hz}, 1 \mathrm{H}, \mathrm{Tp}\right), 6.21(\mathrm{~m}, 2 \mathrm{H}, \mathrm{Tp}), 6.17(\mathrm{t}$, $\left.J_{\mathrm{H}-\mathrm{H}}=2.3 \mathrm{~Hz}, 1 \mathrm{H}, \mathrm{Tp}\right), 6.09\left(\mathrm{t}, J_{\mathrm{H}-\mathrm{H}}=2.2 \mathrm{~Hz}, 1 \mathrm{H}, \mathrm{Tp}\right)$, $5.92\left(\mathrm{t}, J_{\mathrm{H}-\mathrm{H}}=2.3 \mathrm{~Hz}, 1 \mathrm{H}, \mathrm{Tp}\right), 3.96\left(\mathrm{~d}, J_{\mathrm{H}-\mathrm{H}}=18.0 \mathrm{~Hz}\right.$, $\left.1 \mathrm{H}, \quad \mathrm{C}_{2} \mathrm{PhCH} H \mathrm{CN}\right), \quad 3.81 \quad\left(\mathrm{~d}, \quad J_{\mathrm{H}-\mathrm{H}}=18.0 \mathrm{~Hz}, \quad 1 \mathrm{H}\right.$, $\mathrm{C}_{2} \mathrm{PhCH} H \mathrm{CN}$ ), 2.22 (s, 3H, Me), 1.92 (s, 3H, Me). ${ }^{31} \mathrm{P}$ NMR $\left(\mathrm{CD}_{3} \mathrm{C}(\mathrm{O}) \mathrm{CD}_{3}\right): \delta$ 35.7. MS $\left(\mathrm{FAB}, \mathrm{Ru}^{102}\right) \mathrm{m} / \mathrm{z}$ : $814.2\left(\mathrm{M}^{+}-\mathrm{Cl}\right), \quad 718.3\left(\mathrm{M}^{+}-\mathrm{Cl}, \quad \mathrm{NC}\left(\mathrm{CH}_{3}\right) \mathrm{CHC}\left(\mathrm{CH}_{3}\right)-\right.$ $\mathrm{NH}), 577.1\left(\mathrm{M}^{+}-\mathrm{Cl}, \mathrm{NC}\left(\mathrm{CH}_{3}\right) \mathrm{CHC}\left(\mathrm{CH}_{3}\right) \mathrm{NH}, \mathrm{C}_{2} \mathrm{PhCH}_{2}-\right.$ $\mathrm{CN}$ ). Anal. Calc. for $\mathrm{C}_{42} \mathrm{H}_{40} \mathrm{BClN}{ }_{9} \mathrm{PRu}$ (849.2): C, 59.41; H, 4.75; N, 14.85. Found: C, 59.27; H, 4.84; N, 14.66\%.

\subsection{Synthesis of $\left(\mathrm{C}_{3} \mathrm{H}_{3} \mathrm{NNH}\right)[\mathrm{Ru}]-\mathrm{N}_{4} \mathrm{CCH}(\mathrm{Ph}) \mathrm{CH}_{2} \mathrm{CN}$ (9a)}

Solution of complex $7 \mathrm{a}(0.2 \mathrm{~g}, 0.21 \mathrm{mmol})$ in $20 \mathrm{~mL}$ $\mathrm{CH}_{2} \mathrm{Cl}_{2}$ was added $\mathrm{Me}_{3} \mathrm{SiN}_{3}(0.2 \mathrm{~mL}, 1.51 \mathrm{mmol})$. After stirring for $10 \mathrm{~h}$, the solvent was removed under vacuum, then the solid residue was extracted with diethyl ether, and the extract was filtered. The resulting solution was removed under vacuum and washed with $5 \mathrm{~mL}$ hexane. The product was dried under vacuum. The yellow product was identified as $9 \mathrm{a}(0.16 \mathrm{~g}, 89 \%$ yield $)$. Spectroscopic data of 9a: IR $\left(\mathrm{KBr}, \mathrm{cm}^{-1}\right): v(\mathrm{~B}-\mathrm{H}) 2486(\mathrm{br}), v(\mathrm{C} \equiv \mathrm{N}) 2235(\mathrm{w})$, $v(\mathrm{~N}=\mathrm{N}) 1432(\mathrm{w}) \mathrm{cm}^{-1} \cdot{ }^{1} \mathrm{H}$ NMR $\left(\mathrm{CDCl}_{3}\right)$ : major isomer: $\delta$ 14.83 (s, 1H, NH), 7.77-6.93 (m, Ph, Tp, HPz), 6.12 (d, $\left.J_{\mathrm{H}-\mathrm{H}}=2.1 \mathrm{~Hz}, 2 \mathrm{H}, \mathrm{Tp}, \mathrm{HPz}\right), 6.07\left(\mathrm{~d}, J_{\mathrm{H}-\mathrm{H}}=2.1 \mathrm{~Hz}\right.$, $2 \mathrm{H}, \mathrm{Tp}, \mathrm{HPz}), 5.90(\mathrm{~s}, 1 \mathrm{H}, \mathrm{Tp}, \mathrm{HPz}), 5.87\left(\mathrm{t}, J_{\mathrm{H}-\mathrm{H}}=\right.$ $2.1 \mathrm{~Hz}, 2 \mathrm{H}, \mathrm{Tp}, \mathrm{HPz}), 5.86\left(\mathrm{t}, J_{\mathrm{H}-\mathrm{H}}=2.0 \mathrm{~Hz}, 2 \mathrm{H}, \mathrm{Tp}\right.$, $\mathrm{HPz}), \quad 4.57\left(\mathrm{dd}, 1 \mathrm{H},{ }^{3} J_{\mathrm{H}-\mathrm{H}}=7.3 \mathrm{~Hz},{ }^{3} J_{\mathrm{H}-\mathrm{H}}=7.2 \mathrm{~Hz}\right.$, $\mathrm{CH}), 3.03,2.85\left(\mathrm{dd}, \mathrm{AB},{ }^{3} J_{\mathrm{H}-\mathrm{H}}=7.3 \mathrm{~Hz},{ }^{3} J_{\mathrm{H}-\mathrm{H}}=7.2 \mathrm{~Hz}\right.$, $\left.{ }^{2} J_{\mathrm{H}-\mathrm{H}}=16.7 \mathrm{~Hz}, 2 \mathrm{H}, \mathrm{CH}_{2}\right)$; minor isomer: $14.77(\mathrm{~s}, 1 \mathrm{H}$, $\mathrm{NH}), 7.77-6.93(\mathrm{~m}, \mathrm{Ph}, \mathrm{Tp}, \mathrm{HPz}), 6.12\left(\mathrm{~d}, J_{\mathrm{H}-\mathrm{H}}=2.1 \mathrm{~Hz}\right.$, $2 \mathrm{H}, \mathrm{Tp}, \mathrm{HPz}), 6.07\left(\mathrm{~d}, J_{\mathrm{H}-\mathrm{H}}=2.1 \mathrm{~Hz}, 2 \mathrm{H}, \mathrm{Tp}, \mathrm{HPz}\right)$, $5.90(\mathrm{~s}, 1 \mathrm{H}, \mathrm{Tp}, \mathrm{HPz}), 5.87\left(\mathrm{t}, J_{\mathrm{H}-\mathrm{H}}=2.1 \mathrm{~Hz}, 2 \mathrm{H}, \mathrm{Tp}\right.$,
$\mathrm{HPz}), 5.86\left(\mathrm{t}, J_{\mathrm{H}-\mathrm{H}}=2.0 \mathrm{~Hz}, 2 \mathrm{H}, \mathrm{Tp}, \mathrm{HPz}\right), 4.57(\mathrm{dd}$, $\left.1 \mathrm{H},{ }^{3} J_{\mathrm{H}-\mathrm{H}}=7.3 \mathrm{~Hz},{ }^{3} J_{\mathrm{H}-\mathrm{H}}=7.2 \mathrm{~Hz}, \mathrm{CH}\right), 3.12,2.94(\mathrm{dd}$, $\mathrm{AB}, \quad{ }^{3} J_{\mathrm{H}-\mathrm{H}}=7.3 \mathrm{~Hz},{ }^{3} J_{\mathrm{H}-\mathrm{H}}=7.2 \mathrm{~Hz},{ }^{2} J_{\mathrm{H}-\mathrm{H}}=16.7 \mathrm{~Hz}$, $\left.2 \mathrm{H}, \mathrm{CH}_{2}\right) \cdot{ }^{13} \mathrm{C}$ NMR $\left(\mathrm{CDCl}_{3}\right)$ major isomer: $\delta 172.1$ (NCN), 147.6-127.4 (m, Ph, Tp, HPz), $118.4(\mathrm{CN}), 39.6$ $(\mathrm{CH}), 24.5\left(\mathrm{CH}_{2}\right)$; minor isomer: $\delta 170.3(\mathrm{NCN}), 149.1-$ 126.3 (m, Ph, Tp, HPz), $119.7(\mathrm{CN}), 38.2(\mathrm{CH}), 21.4$ $\left(\mathrm{CH}_{2}\right) .{ }^{31} \mathrm{P}$ NMR $\left(\mathrm{CD}_{3} \mathrm{C}(\mathrm{O}) \mathrm{CD}_{3}, \mathrm{ppm}\right): \delta 54.6,54.5(3: 2)$. MS (FAB) $m / z: \quad 843.4 \quad\left(\mathrm{M}^{+}\right), \quad 645.2 \quad\left(\mathrm{M}^{+}-\mathrm{N}_{4} \mathrm{CCH}-\right.$ $\left.(\mathrm{Ph}) \mathrm{CH}_{2} \mathrm{CN}\right), \quad 577.1 \quad\left(\mathrm{M}^{+}-\mathrm{N}_{4} \mathrm{CCH}(\mathrm{Ph}) \mathrm{CH}_{2} \mathrm{CN}, \mathrm{HPz}\right)$. Anal. Calc. for $\mathrm{C}_{40} \mathrm{H}_{37} \mathrm{BN}_{13} \mathrm{PRu}$ (843.2): $\mathrm{C}, 57.01 ; \mathrm{H}$, 4.43; N, 21.61. Found: C, 57.07; H, 4.51; N, 21.46\%.

\subsection{Synthesis of $\left(\mathrm{Me}_{2} \mathrm{C}_{3} \mathrm{HNNH}\right)[\mathrm{Ru}]-\mathrm{N}_{4} \mathrm{CCH}(\mathrm{Ph})-$ $\mathrm{CH}_{2} \mathrm{CN}(\mathbf{9 b})$}

Solution of complex $7 \mathbf{b}(0.65 \mathrm{~g}, 0.80 \mathrm{mmol})$ in $20 \mathrm{~mL}$ $\mathrm{CH}_{2} \mathrm{Cl}_{2}$ was added $\mathrm{Me}_{3} \mathrm{SiN}_{3}(0.6 \mathrm{~mL}, 4.0 \mathrm{mmol})$. After stirring for $10 \mathrm{~h}$, the solvent was removed under vacuum, then the solid residue was extracted with diethyl ether, and the extract was filtered. The resulting solution was removed under vacuum and washed with $5 \mathrm{~mL}$ hexane. The product was dried under vacuum. The yellow product was identified as $9 \mathbf{b}(0.51 \mathrm{~g}, 73 \%$ yield $)$. Spectroscopic data of $9 \mathbf{b}$ : IR $\left(\mathrm{KBr}, \mathrm{cm}^{-1}\right): v(\mathrm{~B}-\mathrm{H}) 2477(\mathrm{br}), v(\mathrm{C} \equiv \mathrm{N}) 2237(\mathrm{w}), v(\mathrm{~N}=\mathrm{N})$ $1433(\mathrm{w}) \mathrm{cm}^{-1} \cdot{ }^{1} \mathrm{H}$ NMR $\left(\mathrm{CDCl}_{3}\right)$ : major isomer: $\delta 13.54$ (s, 1H, NH), 7.91-6.87 (m, Ph, Tp), 6.57 (br, 2H, Tp), $6.16\left(\mathrm{~d}, J_{\mathrm{H}-\mathrm{H}}=2.0 \mathrm{~Hz}, 3 \mathrm{H}, \mathrm{Tp}, \mathrm{HPz}\right), 6.04(\mathrm{~s}, 2 \mathrm{H}, \mathrm{Tp})$, $5.85\left(\mathrm{t}, J_{\mathrm{H}-\mathrm{H}}=2.1 \mathrm{~Hz}, 2 \mathrm{H}, \mathrm{Tp}, \mathrm{HPz}\right), 5.72\left(\mathrm{t}, J_{\mathrm{H}-\mathrm{H}}=\right.$ $1.9 \mathrm{~Hz}, 2 \mathrm{H}, \mathrm{Tp}, \mathrm{HPz}), 4.43\left(\mathrm{dd}, 1 \mathrm{H},{ }^{3} J_{\mathrm{H}-\mathrm{H}}=7.4 \mathrm{~Hz}\right.$, $\left.{ }^{3} J_{\mathrm{H}-\mathrm{H}}=7.4 \mathrm{~Hz}, \mathrm{CH}\right), 3.11,2.93\left(\mathrm{dd}, \mathrm{AB},{ }^{3} J_{\mathrm{H}-\mathrm{H}}=7.4 \mathrm{~Hz}\right.$, $\left.{ }^{3} J_{\mathrm{H}-\mathrm{H}}=7.4 \mathrm{~Hz},{ }^{2} J_{\mathrm{H}-\mathrm{H}}=16.5 \mathrm{~Hz}, 2 \mathrm{H}, \mathrm{CH}_{2}\right), 2.18,2.10(\mathrm{~s}$, $\left.3 \mathrm{H}, \mathrm{CH}_{3}\right)$; minor isomer: $13.47(\mathrm{~s}, 1 \mathrm{H}, \mathrm{NH}), 7.91-6.87$ (m, Ph, Tp), $6.57(\mathrm{br}, 2 \mathrm{H}, \mathrm{Tp}), 6.16\left(\mathrm{~d}, J_{\mathrm{H}-\mathrm{H}}=2.0 \mathrm{~Hz}\right.$, $3 \mathrm{H}, \mathrm{Tp}, \mathrm{HPz}), 6.04(\mathrm{~s}, 2 \mathrm{H}, \mathrm{Tp}), 5.85\left(\mathrm{t}, J_{\mathrm{H}-\mathrm{H}}=2.1 \mathrm{~Hz}\right.$, $2 \mathrm{H}, \mathrm{Tp}, \mathrm{HPz}), 5.72\left(\mathrm{t}, J_{\mathrm{H}-\mathrm{H}}=1.9 \mathrm{~Hz}, 2 \mathrm{H}, \mathrm{Tp}, \mathrm{HPz}\right), 4.43$ $\left(\mathrm{dd}, 1 \mathrm{H},{ }^{3} J_{\mathrm{H}-\mathrm{H}}=7.4 \mathrm{~Hz},{ }^{3} J_{\mathrm{H}-\mathrm{H}}=7.4 \mathrm{~Hz}, \mathrm{CH}\right), 3.20,2.86$ $\left(\mathrm{dd}, \quad \mathrm{AB},{ }^{3} J_{\mathrm{H}-\mathrm{H}}=7.4 \mathrm{~Hz},{ }^{3} J_{\mathrm{H}-\mathrm{H}}=7.4 \mathrm{~Hz},{ }^{2} J_{\mathrm{H}-\mathrm{H}}=\right.$ $\left.16.5 \mathrm{~Hz}, 2 \mathrm{H}, \mathrm{CH}_{2}\right), 2.21,2.08\left(\mathrm{~s}, 3 \mathrm{H}, \mathrm{CH}_{3}\right) .{ }^{31} \mathrm{P}$ NMR $\left(\mathrm{CD}_{3} \mathrm{C}(\mathrm{O}) \mathrm{CD}_{3}, \mathrm{ppm}\right): \delta$ 54.1, 53.8 (3:2). MS (FAB) $\mathrm{m} / \mathrm{z}$ : $873.1\left(\mathrm{M}^{+}\right), \quad 645.2 \quad\left(\mathrm{M}^{+}-\mathrm{N}_{4} \mathrm{CCH}(\mathrm{Ph}) \mathrm{CH}_{2} \mathrm{CN}\right), \quad 577.1$ $\left(\mathrm{M}^{+}-\mathrm{N}_{4} \mathrm{CCH}(\mathrm{Ph}) \mathrm{CH}_{2} \mathrm{CN}, \mathrm{Me}_{2} \mathrm{C}_{3} \mathrm{~N}_{2} \mathrm{H}_{2}\right)$. Anal. Calc. for $\mathrm{C}_{42} \mathrm{H}_{41} \mathrm{BN}_{13} \mathrm{PRu}$ (871.7): C, 57.93; H, 4.75; N, 20.91. Found: C, 57.83; H, 4.84; N, 20.78\%.

\subsection{Synthesis of $\left\{\left(\mathrm{C}_{3} \mathrm{H}_{3} N N H\right)[R u]=C=C(P h)-\right.$ $\mathrm{CH}(\mathrm{HgCl}) \mathrm{CN}\} \mathrm{Cl}(\mathbf{1 0 a})$}

To a solid mixture of $7 \mathbf{a}(0.27 \mathrm{~g}, 0.29 \mathrm{mmol})$ and $\mathrm{HgCl}_{2}$ $(0.096 \mathrm{~g}, 0.35 \mathrm{mmol}), 30 \mathrm{~mL}$ of $\mathrm{CH}_{2} \mathrm{Cl}_{2}$ was added. The mixture was stirred for $10 \mathrm{~min}$ at $-20{ }^{\circ} \mathrm{C}$ then the solvent was removed under vacuum. The residual solid was extracted with $2 \times 20 \mathrm{~mL}$ ether and, after filtration, the solvent was removed under vacuum to give $10 \mathrm{a}(0.22 \mathrm{~g}$, $73 \%$ yield). Spectroscopic data of $10 a:{ }^{1} \mathrm{H}$ NMR $\left(\mathrm{CD}_{3} \mathrm{C}(\mathrm{O}) \mathrm{CD}_{3}\right): \delta 8.10\left(\mathrm{~d}, J_{\mathrm{H}-\mathrm{H}}=2.0 \mathrm{~Hz}, 1 \mathrm{H}, \mathrm{Tp}\right), 8.01$ $\left(\mathrm{d}, J_{\mathrm{H}-\mathrm{H}}=2.2 \mathrm{~Hz}, 1 \mathrm{H}, \mathrm{Tp}\right), 7.74-6.51(\mathrm{~m}, \mathrm{Ph}, \mathrm{Tp}), 6.52$ 
$\left(\mathrm{d}, J_{\mathrm{H}-\mathrm{H}}=2.3 \mathrm{~Hz}, 1 \mathrm{H}, \mathrm{Tp}\right), 6.41\left(\mathrm{~d}, J_{\mathrm{H}-\mathrm{H}}=2.3 \mathrm{~Hz}, \mathrm{Tp}\right)$, $6.13(\mathrm{~m}, 2 \mathrm{H}, \mathrm{Tp}), 5.92\left(\mathrm{~d}, J_{\mathrm{H}-\mathrm{H}}=2.1 \mathrm{~Hz}, 1 \mathrm{H}, \mathrm{Tp}\right), 3.93$ $\left(\mathrm{d}, J_{\mathrm{H}-\mathrm{H}}=16.9 \mathrm{~Hz}, 1 \mathrm{H}, \mathrm{C}_{2} \mathrm{PhCH} H \mathrm{CN}\right), 3.73\left(\mathrm{~d}, J_{\mathrm{H}-\mathrm{H}}=\right.$ 16.9 Hz, $\left.1 \mathrm{H}, \mathrm{C}_{2} \mathrm{PhCH} H \mathrm{CN}\right) .{ }^{13} \mathrm{C} \mathrm{NMR}\left(\mathrm{CD}_{3} \mathrm{C}(\mathrm{O}) \mathrm{CD}_{3}\right)$ : $\delta 379.3\left(\mathrm{~d}, J_{\mathrm{P}-\mathrm{C}}=16.1 \mathrm{~Hz}, \mathrm{C}_{\alpha}\right), 149.6-121.2\left(\mathrm{Ph}, \mathrm{PPh}_{3}\right.$, $\mathrm{Tp}), 118.2(\mathrm{CN}), 15.6\left(\mathrm{CH}_{2}\right) .{ }^{31} \mathrm{P} \mathrm{NMR}\left(\mathrm{CD}_{3} \mathrm{C}(\mathrm{O}) \mathrm{CD}_{3}\right)$ : $\delta$ 36.2. MS (FAB) $m / z: 1023.3\left(\mathrm{M}^{+}-\mathrm{Cl}\right), 718.3\left(\mathrm{M}^{+}-\mathrm{Cl}\right.$, $\mathrm{NCHCHCHN}(\mathrm{HgCl})), \quad 577.1\left(\mathrm{M}^{+}-\mathrm{Cl}, \mathrm{NCHCHCHN}-\right.$ $\left.(\mathrm{HgCl}), \mathrm{C}_{2} \mathrm{PhCH}_{2} \mathrm{CN}\right)$. Anal. Calc. for $\mathrm{C}_{40} \mathrm{H}_{35} \mathrm{BCl}_{2} \mathrm{Hg}-$ $\mathrm{N}_{9} \mathrm{PRu}(1057.1): \mathrm{C}, 45.49 ; \mathrm{H}, 3.34 ; \mathrm{N}, 11.94$. Found: C, $45.47 ; \mathrm{H}, 3.54 ; \mathrm{N}, 11.48 \%$.

\subsection{Synthesis of $\left\{\left(\mathrm{Me}_{2} \mathrm{C}_{3} \mathrm{HNNH}\right)[\mathrm{Ru}]=C=\mathrm{C}(\mathrm{Ph})-\right.$ $\mathrm{CH}(\mathrm{HgCl}) \mathrm{CN}\} \mathrm{Cl}(\mathbf{1 0 b})$}

To a solid mixture of $7 \mathbf{b}(0.31 \mathrm{~g}, 0.41 \mathrm{mmol})$ and $\mathrm{HgCl}_{2}$ $(0.11 \mathrm{~g}, 0.41 \mathrm{mmol}), 30 \mathrm{~mL}$ of $\mathrm{CH}_{2} \mathrm{Cl}_{2}$ was added. The mixture was stirred for $10 \mathrm{~min}$ at $-20^{\circ} \mathrm{C}$ then the solvent was removed under vacuum. The residual solid was extracted with $2 \times 20 \mathrm{~mL}$ ether and, after filtration, the solvent was removed under vacuum to give $\mathbf{1 0 b}(0.21 \mathrm{~g}, 65 \%$ yield $)$. Spectroscopic data of 10b: ${ }^{1} \mathrm{H}$ NMR $\left(\mathrm{CD}_{3} \mathrm{C}(\mathrm{O}) \mathrm{CD}_{3}\right): \delta$ $8.03\left(\mathrm{~d}, J_{\mathrm{H}-\mathrm{H}}=2.1 \mathrm{~Hz}, 1 \mathrm{H}, \mathrm{Tp}\right), 7.95\left(\mathrm{~d}, J_{\mathrm{H}-\mathrm{H}}=2.0 \mathrm{~Hz}\right.$, $1 \mathrm{H}, \mathrm{Tp}), \quad 7.69-6.77(\mathrm{~m}, \mathrm{Ph}, \mathrm{Tp}), 6.63\left(\mathrm{~d}, J_{\mathrm{H}-\mathrm{H}}=\right.$ $2.0 \mathrm{~Hz}, 1 \mathrm{H}, \mathrm{Tp}), 6.52\left(\mathrm{~d}, J_{\mathrm{H}-\mathrm{H}}=1.9 \mathrm{~Hz}, \mathrm{Tp}\right), 6.23(\mathrm{~m}, 2 \mathrm{H}$, $\mathrm{Tp}), 5.89\left(\mathrm{~d}, J_{\mathrm{H}-\mathrm{H}}=2.1 \mathrm{~Hz}, 1 \mathrm{H}, \mathrm{Tp}\right), 3.89\left(\mathrm{~d}, J_{\mathrm{H}-\mathrm{H}}=\right.$ $\left.16.7 \mathrm{~Hz}, 1 \mathrm{H}, \mathrm{C}_{2} \mathrm{PhCH} H \mathrm{CN}\right), 3.71\left(\mathrm{~d}, J_{\mathrm{H}-\mathrm{H}}=16.7 \mathrm{~Hz}\right.$, $\left.1 \mathrm{H}, \mathrm{C}_{2} \mathrm{PhCH} H \mathrm{CN}\right), 2.31$ (s, 3H, Me), $2.01(\mathrm{~s}, 3 \mathrm{H}, \mathrm{Me})$. ${ }^{31} \mathrm{P}$ NMR $\left(\mathrm{CD}_{3} \mathrm{C}(\mathrm{O}) \mathrm{CD}_{3}\right): \delta$ 36.8. MS (FAB) $\mathrm{m} / \mathrm{z}: 1053.1$ $\left(\mathrm{M}^{+}-\mathrm{Cl}\right), \quad 718.3 \quad\left(\mathrm{M}^{+}-\mathrm{Cl}, \quad \mathrm{NMe}_{2} \mathrm{C}_{3} \mathrm{HN}(\mathrm{HgCl})\right), \quad 577.1$ $\left(\mathrm{M}^{+}-\mathrm{Cl}, \mathrm{NMe}_{2} \mathrm{C}_{3} \mathrm{HN}(\mathrm{HgCl}), \mathrm{C}_{2} \mathrm{PhCH}_{2} \mathrm{CN}\right)$. Anal. Calc. for $\mathrm{C}_{42} \mathrm{H}_{39} \mathrm{BCl}_{2} \mathrm{HgN}_{9} \mathrm{PRu}(1085.1)$ : C, 46.53; H, 3.63; N, 11.63. Found: C, 46.27; H, 3.64; N, 11.44\%.

\subsection{Synthesis of $\left\{\left(\mathrm{C}_{3} \mathrm{H}_{3} \mathrm{NNH}\right)[\mathrm{Ru}]-\mathrm{N}_{4}(\mathrm{H}) \mathrm{CCH}(\mathrm{Ph})-\right.$ $\left.\mathrm{CH}_{2} \mathrm{CN}\right\} \mathrm{Cl}(\mathbf{1 1})$}

Solution of tetrazolate complex 9a (10 mg, $0.012 \mathrm{mmol})$ in $\mathrm{CDCl}_{3}$ prepared under $\mathrm{N}_{2}$ in NMR tube, one drop $(5 \mu \mathrm{L})$ of $\mathrm{HCl}$ was added. The reaction accomplished immediately. The solvent was removed under vacuum over $5 \mathrm{~h}$ at $60^{\circ} \mathrm{C}$. The green product was washed with hexane, dried under vacuum and identified as $\left\{\left(\mathrm{C}_{3} \mathrm{H}_{3} \mathrm{NNH}\right)[\mathrm{Ru}]\right.$ $\left.\mathrm{N}_{4}(\mathrm{H}) \mathrm{CCH}(\mathrm{Ph}) \mathrm{CH}_{2} \mathrm{CN}\right\} \mathrm{Cl}$. Spectroscopic data of 11: IR $\left(\mathrm{KBr}, \mathrm{cm}^{-1}\right): v(\mathrm{~B}-\mathrm{H}) 2483(\mathrm{br}), v(\mathrm{C} \equiv \mathrm{N}) 2243(\mathrm{w}), v(\mathrm{~N}=\mathrm{N})$ $1448(\mathrm{~m}) \mathrm{cm}^{-1} .{ }^{1} \mathrm{H}$ NMR $\left(\mathrm{CDCl}_{3}, \mathrm{ppm}\right)$ : major isomer: $\delta$ $13.51(\mathrm{~s}, 1 \mathrm{H}, \mathrm{N} H), 13.12$ (s, 1H, NHCCH(Ph)), 7.89-6.86 (m, Ph, Tp, HPz), $6.11\left(\mathrm{~d}, J_{\mathrm{H}-\mathrm{H}}=2.2 \mathrm{~Hz}, 2 \mathrm{H}, \mathrm{Tp}, \mathrm{HPz}\right)$, $6.15\left(\mathrm{~d}, J_{\mathrm{H}-\mathrm{H}}=2.2 \mathrm{~Hz}, 2 \mathrm{H}, \mathrm{Tp}, \mathrm{HPz}\right), 5.94(\mathrm{~s}, 1 \mathrm{H}, \mathrm{Tp}$, $\mathrm{HPz}), 5.80\left(\mathrm{t}, J_{\mathrm{H}-\mathrm{H}}=2.2 \mathrm{~Hz}, 2 \mathrm{H}, \mathrm{Tp}, \mathrm{HPz}\right), 5.76(\mathrm{t}$, $\left.J_{\mathrm{H}-\mathrm{H}}=2.2 \mathrm{~Hz}, 2 \mathrm{H}, \mathrm{Tp}, \mathrm{HPz}\right), 4.49\left(\mathrm{dd}, 1 \mathrm{H},{ }^{3} J_{\mathrm{H}-\mathrm{H}}=\right.$ $\left.7.4 \mathrm{~Hz},{ }^{3} J_{\mathrm{H}-\mathrm{H}}=7.3 \mathrm{~Hz}, \mathrm{CH}\right), 3.11,2.97\left(\mathrm{dd}, \mathrm{AB},{ }^{3} J_{\mathrm{H}-\mathrm{H}}=\right.$ $\left.7.4 \mathrm{~Hz},{ }^{3} J_{\mathrm{H}-\mathrm{H}}=7.3 \mathrm{~Hz},{ }^{2} J_{\mathrm{H}-\mathrm{H}}=16.8 \mathrm{~Hz}, 2 \mathrm{H}, \mathrm{CH}_{2}\right)$; minor isomer: $13.3(\mathrm{~s}, 1 \mathrm{H}, \mathrm{NH}), 13.1(\mathrm{~s}, 1 \mathrm{H}, \mathrm{NHCCH}(\mathrm{Ph})), 7.89$ $6.86(\mathrm{~m}, \mathrm{Ph}, \mathrm{Tp}, \mathrm{HPz}), 6.15\left(\mathrm{~d}, J_{\mathrm{H}-\mathrm{H}}=2.2 \mathrm{~Hz}, 2 \mathrm{H}, \mathrm{Tp}\right.$, $\mathrm{HPz}), 6.11\left(\mathrm{~d}, J_{\mathrm{H}-\mathrm{H}}=2.2 \mathrm{~Hz}, 2 \mathrm{H}, \mathrm{Tp}, \mathrm{HPz}\right), 5.94(\mathrm{~s}, 1 \mathrm{H}$, $\mathrm{Tp}, \mathrm{HPz}), 5.80\left(\mathrm{t}, J_{\mathrm{H}-\mathrm{H}}=2.2 \mathrm{~Hz}, 2 \mathrm{H}, \mathrm{Tp}, \mathrm{HPz}\right), 5.76(\mathrm{t}$,
$\left.J_{\mathrm{H}-\mathrm{H}}=2.2 \mathrm{~Hz}, 2 \mathrm{H}, \mathrm{Tp}, \mathrm{HPz}\right), 4.39\left(\mathrm{dd}, 1 \mathrm{H},{ }^{3} J_{\mathrm{H}-\mathrm{H}}=\right.$ $\left.7.3 \mathrm{~Hz}, \quad{ }^{3} J_{\mathrm{H}-\mathrm{H}}=7.2 \mathrm{~Hz}, \quad \mathrm{CH}\right), \quad 3.21, \quad 2.91(\mathrm{dd}, \quad \mathrm{AB}$, ${ }^{3} J_{\mathrm{H}-\mathrm{H}}=7.3 \mathrm{~Hz}, \quad{ }^{3} J_{\mathrm{H}-\mathrm{H}}=7.2 \mathrm{~Hz}, \quad{ }^{2} J_{\mathrm{H}-\mathrm{H}}=16.8 \mathrm{~Hz}, \quad 2 \mathrm{H}$, $\left.\mathrm{CH}_{2}\right) .{ }^{31} \mathrm{P}$ NMR $\left(\mathrm{CD}_{3} \mathrm{C}(\mathrm{O}) \mathrm{CD}_{3}, \mathrm{ppm}\right): \delta 53.7,53.5(3: 2)$. MS (FAB) $m / z: 844.3\left(\mathbf{M}^{+}\right.$), MS (FAB) $m / z: 844.3\left(\mathbf{M}^{+}\right)$, $776.2\left(\mathrm{M}^{+}-\mathrm{HPz}\right), 577.1\left(\mathrm{M}^{+}-\mathrm{HPz}, \mathrm{HN}_{4} \mathrm{CCH}(\mathrm{Ph}) \mathrm{CH}_{2^{-}}\right.$ $\mathrm{CN}$ ). Anal. Calc. for $\mathrm{C}_{40} \mathrm{H}_{38} \mathrm{BClN}_{13} \mathrm{PRu}$ (879.2): C, $54.65 ; \mathrm{H}, 4.36 ; \mathrm{N}, 20.71$. Found: $\mathrm{C}, 54.49 ; \mathrm{H}, 4.33 ; \mathrm{N}$, $20.54 \%$.

\subsection{Synthesis of $\left\{\left(\mathrm{C}_{3} \mathrm{H}_{3} \mathrm{NNH}\right)[\mathrm{Ru}] \mathrm{N}_{4}\left(\mathrm{CH}_{3}\right) \mathrm{CCH}(\mathrm{Ph})\right.$ - $\left.\mathrm{CH}_{2} \mathrm{CN}\right\} \mathrm{I}(12 \mathrm{a})$}

Solution of tetrazolate complex 9a (10 mg, $0.012 \mathrm{mmol})$ in $\mathrm{CDCl}_{3}$ prepared under $\mathrm{N}_{2}$ in NMR tube, one drop $(5 \mu \mathrm{L})$ of $\mathrm{CH}_{3} \mathrm{I}$ was added. The reaction was carried out at $50{ }^{\circ} \mathrm{C}$ for $10 \mathrm{~h}$, and the color changed from yellow to green. Then the solvent and excess of $\mathrm{CH}_{3} \mathrm{I}$ were removed under vacuum. The green product was extracted with diethyl ether, and passed through a silica column. A 1:1 diethyl ether-hexane solution eluted the organometallic compound, $\left\{\left(\mathrm{C}_{3} \mathrm{H}_{3} \mathrm{NNH}\right)[\mathrm{Ru}] \mathrm{N}_{4}\left(\mathrm{CH}_{3}\right) \mathrm{CCH}(\mathrm{Ph}) \mathrm{CH}_{2} \mathrm{CN}\right\} \mathrm{I}$. Spectroscopic data of 12a: IR $\left(\mathrm{KBr}, \mathrm{cm}^{-1}\right): v(\mathrm{~B}-\mathrm{H})$ 2481(br), $v(\mathrm{C} \equiv \mathrm{N}) 2242(\mathrm{w}), v(\mathrm{~N}=\mathrm{N}) 1449(\mathrm{~m}) \mathrm{cm}^{-1} \cdot{ }^{1} \mathrm{H}$ NMR $\left(\mathrm{CDCl}_{3}, \mathrm{ppm}\right):{ }^{1} \mathrm{H}$ NMR $\left(\mathrm{CDCl}_{3}, \mathrm{ppm}\right)$ : major isomer: $\delta 13.56(\mathrm{~s}, 1 \mathrm{H}, \mathrm{NH}), 7.79-6.12(\mathrm{~m}, \mathrm{Ph}, \mathrm{Tp}, \mathrm{HPz}), 6.15$ $\left(\mathrm{d}, J_{\mathrm{H}-\mathrm{H}}=2.2 \mathrm{~Hz}, 2 \mathrm{H}, \mathrm{Tp}, \mathrm{HPz}\right), 5.86(\mathrm{~s}, 1 \mathrm{H}, \mathrm{Tp}, \mathrm{HPz})$, $5.73\left(\mathrm{t}, J_{\mathrm{H}-\mathrm{H}}=2.2 \mathrm{~Hz}, 2 \mathrm{H}, \mathrm{Tp}, \mathrm{HPz}\right), 5.67\left(\mathrm{t}, J_{\mathrm{H}-\mathrm{H}}=\right.$ $2.2 \mathrm{~Hz}, 2 \mathrm{H}, \mathrm{Tp}, \mathrm{HPz}), 4.45\left(\mathrm{dd}, 1 \mathrm{H},{ }^{3} J_{\mathrm{H}-\mathrm{H}}=7.3 \mathrm{~Hz}\right.$, $\left.{ }^{3} J_{\mathrm{H}-\mathrm{H}}=7.4 \mathrm{~Hz}, \mathrm{CH}\right), 3.67\left(\mathrm{~s}, 3 \mathrm{H}, \mathrm{CH}_{3}\right), 3.08,2.89(\mathrm{dd}$, $\mathrm{AB},{ }^{3} J_{\mathrm{H}-\mathrm{H}}=7.3 \mathrm{~Hz},{ }^{3} J_{\mathrm{H}-\mathrm{H}}=7.4 \mathrm{~Hz},{ }^{2} J_{\mathrm{H}-\mathrm{H}}=16.8 \mathrm{~Hz}$, $\left.2 \mathrm{H}, \mathrm{CH}_{2}\right)$; minor isomer: $13.41(\mathrm{~s}, 1 \mathrm{H}, \mathrm{NH}), 7.79-6.12$ (m, Ph, Tp, HPz), 6.15 (d, $J_{\mathrm{H}-\mathrm{H}}=2.2 \mathrm{~Hz}, 2 \mathrm{H}, \mathrm{Tp}, \mathrm{HPz}$ ), $5.86(\mathrm{~s}, 1 \mathrm{H}, \mathrm{Tp}, \mathrm{HPz}), 5.73\left(\mathrm{t}, J_{\mathrm{H}-\mathrm{H}}=2.2 \mathrm{~Hz}, 2 \mathrm{H}, \mathrm{Tp}\right.$, $\mathrm{HPz}), 5.67\left(\mathrm{t}, J_{\mathrm{H}-\mathrm{H}}=2.2 \mathrm{~Hz}, 2 \mathrm{H}, \mathrm{Tp}, \mathrm{HPz}\right), 4.31(\mathrm{dd}$, $\left.1 \mathrm{H},{ }^{3} J_{\mathrm{H}-\mathrm{H}}=7.3 \mathrm{~Hz},{ }^{3} J_{\mathrm{H}-\mathrm{H}}=7.2 \mathrm{~Hz}, \mathrm{CH}\right), 3.76(\mathrm{~s}, 3 \mathrm{H}$, $\left.\mathrm{CH}_{3}\right), \quad 3.19, \quad 3.01\left(\mathrm{dd}, \quad \mathrm{AB},{ }^{3} J_{\mathrm{H}-\mathrm{H}}=7.3 \mathrm{~Hz},{ }^{3} J_{\mathrm{H}-\mathrm{H}}=\right.$ $\left.7.2 \mathrm{~Hz}, \quad{ }^{2} J_{\mathrm{H}-\mathrm{H}}=16.9 \mathrm{~Hz}, \quad 2 \mathrm{H}, \quad \mathrm{CH}_{2}\right) . \quad{ }^{31} \mathrm{P} \quad \mathrm{NMR}$ $\left(\mathrm{CD}_{3} \mathrm{C}(\mathrm{O}) \mathrm{CD}_{3}, \mathrm{ppm}\right): \delta 51.0,50.9$ (3:2). MS (FAB) $\mathrm{m} / \mathrm{z}$ : $858.3\left(\mathrm{M}^{+}\right), 790.3\left(\mathrm{M}^{+}-\mathrm{HPz}\right), 577.1\left(\mathrm{M}^{+}-\mathrm{MeN}_{4} \mathrm{CCH}-\right.$ $(\mathrm{Ph}) \mathrm{CH}_{2} \mathrm{CN}, \mathrm{HPz}$ ). Anal. Calc. for $\mathrm{C}_{41} \mathrm{H}_{40} \mathrm{BIN}_{13} \mathrm{PRu}$ (985.1): C, 50.01; H, 4.09; N, 18.49. Found: C, 50.11; H, $4.16 ; \mathrm{N}, 18.37 \%$.

\subsection{Synthesis of $\left\{\left(\mathrm{C}_{3} \mathrm{H}_{3} \mathrm{NNH}\right)[\mathrm{Ru}] \mathrm{N}_{4}\left(\mathrm{CH}_{2} \mathrm{Ph}\right)\right.$ - $\left.\mathrm{CCH}(\mathrm{Ph}) \mathrm{CH}_{2} \mathrm{CN}\right\} \mathrm{Br}(\mathbf{1 2 b})$}

Solution of tetrazolate complex 9a (10 mg, $0.012 \mathrm{mmol})$ in $\mathrm{CDCl}_{3}$ prepared under $\mathrm{N}_{2}$ in NMR tube, one drop (ca. $5 \mu \mathrm{L})$ of $\mathrm{PhCH}_{2} \mathrm{Br}$ was added. The reaction was carried out at $50^{\circ} \mathrm{C}$ for $10 \mathrm{~h}$, and the color changed from yellow to red. Then the solvent and excess of $\mathrm{PhCH}_{2} \mathrm{Br}$ were removed under vacuum over $5 \mathrm{~h}$ at $80^{\circ} \mathrm{C}$. The organic product was extracted with diethyl ether, and passed through a silica column. A 1:1 diethyl ether-hexane solution eluted the organometallic compound, $\left\{\left(\mathrm{C}_{3} \mathrm{H}_{3} \mathrm{NNH}\right)[\mathrm{Ru}] \mathrm{N}_{4}\left(\mathrm{CH}_{2} \mathrm{Ph}\right) \mathrm{CCH}-\right.$ $\left.(\mathrm{Ph}) \mathrm{CH}_{2} \mathrm{CN}\right\} \mathrm{Br}$. Spectroscopic data of $\mathbf{1 2 b}$ : IR $(\mathrm{KBr}$, 
$\left.\mathrm{cm}^{-1}\right): v(\mathrm{~B}-\mathrm{H}) 2492(\mathrm{br}), v(\mathrm{C} \equiv \mathrm{N}) 2240(\mathrm{w}), v(\mathrm{~N}=\mathrm{N}) 1450(\mathrm{~m})$ $\mathrm{cm}^{-1} .{ }^{1} \mathrm{H} \mathrm{NMR}\left(\mathrm{CDCl}_{3}, \mathrm{ppm}\right)$ : major isomer: $\delta 14.12(\mathrm{~s}, 1 \mathrm{H}$, $\mathrm{NH}), 7.68-6.34(\mathrm{~m}, \mathrm{Ph}, \mathrm{Tp}, \mathrm{HPz}), 6.11\left(\mathrm{~d}, J_{\mathrm{H}-\mathrm{H}}=2.3 \mathrm{~Hz}\right.$, $2 \mathrm{H}, \mathrm{Tp}, \mathrm{HPz}), 5.89(\mathrm{~s}, 1 \mathrm{H}, \mathrm{Tp}, \mathrm{HPz}), 5.77\left(\mathrm{t}, J_{\mathrm{H}-}\right.$ $\mathrm{H}=2.3 \mathrm{~Hz}, 2 \mathrm{H}, \mathrm{Tp}, \mathrm{HPz}), 5.65\left(\mathrm{t}, J_{\mathrm{H}-\mathrm{H}}=2.3 \mathrm{~Hz}, 2 \mathrm{H}, \mathrm{Tp}\right.$, $\mathrm{HPz}), 4.65\left(\mathrm{dd}, 1 \mathrm{H},{ }^{3} J_{\mathrm{H}-\mathrm{H}}=7.3 \mathrm{~Hz},{ }^{3} J_{\mathrm{H}-\mathrm{H}}=7.4 \mathrm{~Hz}, \mathrm{CH}\right)$, $4.23\left(\mathrm{~s}, 2 \mathrm{H}, \mathrm{CH}_{2} \mathrm{Ph}\right), 3.11,2.96\left(\mathrm{dd}, \mathrm{AB},{ }^{3} J_{\mathrm{H}-\mathrm{H}}=7.3 \mathrm{~Hz}\right.$, ${ }^{3} J_{\mathrm{H}-\mathrm{H}}=7.4 \mathrm{~Hz}$,

$\left.{ }^{2} J_{\mathrm{H}-\mathrm{H}}=16.9 \mathrm{~Hz}, 2 \mathrm{H}, \mathrm{CH}_{2}\right)$; minor isomer: $13.89(\mathrm{~s}, 1 \mathrm{H}$, $\mathrm{NH}), 7.68-6.34(\mathrm{~m}, \mathrm{Ph}, \mathrm{Tp}, \mathrm{HPz}), 6.11\left(\mathrm{~d}, J_{\mathrm{H}-\mathrm{H}}=2.3 \mathrm{~Hz}\right.$, $2 \mathrm{H}, \mathrm{Tp}, \mathrm{HPz}), 5.89(\mathrm{~s}, 1 \mathrm{H}, \mathrm{Tp}, \mathrm{HPz}), 5.77\left(\mathrm{t}, J_{\mathrm{H}-\mathrm{H}}=\right.$ $2.3 \mathrm{~Hz}, 2 \mathrm{H}, \mathrm{Tp}, \mathrm{HPz}), 5.65\left(\mathrm{t}, J_{\mathrm{H}-\mathrm{H}}=2.3 \mathrm{~Hz}, 2 \mathrm{H}, \mathrm{Tp}\right.$, $\mathrm{HPz}), 4.36\left(\mathrm{dd}, 1 \mathrm{H},{ }^{3} J_{\mathrm{H}-\mathrm{H}}=7.4 \mathrm{~Hz},{ }^{3} J_{\mathrm{H}-\mathrm{H}}=7.3 \mathrm{~Hz}, \mathrm{CH}\right)$, $4.54\left(\mathrm{~s}, 2 \mathrm{H}, \mathrm{CH}_{2} \mathrm{Ph}\right), 3.18,3.01\left(\mathrm{dd}, \mathrm{AB},{ }^{3} J_{\mathrm{H}-\mathrm{H}}=7.3 \mathrm{~Hz}\right.$, $\left.{ }^{3} J_{\mathrm{H}-\mathrm{H}}=7.2 \mathrm{~Hz},{ }^{2} J_{\mathrm{H}-\mathrm{H}}=16.9 \mathrm{~Hz}, 2 \mathrm{H}, \mathrm{CH}_{2}\right) .{ }^{31} \mathrm{P} \mathrm{NMR}$ $\left(\mathrm{CD}_{3} \mathrm{C}(\mathrm{O}) \mathrm{CD}_{3}, \mathrm{ppm}\right): \delta 50.8,50.7$ (3:2). MS (FAB) $\mathrm{m} / \mathrm{z}$ : $934.3\left(\mathrm{M}^{+}\right), 866.2\left(\mathrm{M}^{+}-\mathrm{HPz}\right), 577.1\left(\mathrm{M}^{+}-\mathrm{HPz}, \mathrm{CH}_{2} \mathrm{Ph}-\right.$ $\left.\mathrm{N}_{4} \mathrm{CCH}(\mathrm{Ph}) \mathrm{CH}_{2} \mathrm{CN}\right)$. Anal. Calc. for $\mathrm{C}_{47} \mathrm{H}_{44} \mathrm{BBrN}_{13} \mathrm{PRu}$ (1013.2): C, 55.69; H, 4.38; N, 17.96. Found: C, 55.59; H, $4.33 ; \mathrm{N}, 17.84 \%$.

\section{Acknowledgement}

Financial support from the National Science Council of Taiwan is greatly appreciated.

\section{References}

[1] (a) S. Trofimenko, Chem. Rev. 93 (1993) 943; (b) N. Kitajima, W.B. Tolman, Prog. Inorg. Chem. 43 (1995) 419 ;

(c) C. Slugove, R. Schmid, K. Kirchner, Coord. Chem. Rev. 185/186 (1999) 109;

(d) N. Marques, A. Sella, J. Takats, Chem. Rev. 102 (2002) 2137.

[2] M.D. Curtis, K.B. Shiu, W.M. Butler, Organometallics 2 (1983) 1475.

[3] (a) F. Pezet, J.C. Daran, I. Sasaki, H. Ait-Haddou, G.G.A. Balavoine, Organometallics 19 (2000) 4008;

(b) m.J. Burk, W. Hems, D. Herzberg, C. Malan, A. Zanotti-Gerosa, Org. Lett. 2 (2000) 4173;

(c) D.A. Alonso, S.J.M. Nordin, P. Roth, T. Tarnai, P.G. Andersson, M. Thommen, U. Pittelkow, J. Org. Chem. 65 (2000) 3116;

(d) M. Yamakawa, H. Ito, R. Noyori, J. Am. Chem. Soc. 122 (2000) 1466;

(e) B.M. Trost, F.D. Toste, A.B. Pinkerton, Chem. Rev. 101 (2001) 2067;

(f) M. Kitamura, M. Tsukamoto, Y. Bessho, M. Yoshimura, U. Kobs, M. Widhalm, R. Noyori, J. Am. Chem. Soc. 124 (2002) 6649 ;

(g) S.N. Ringelberg, A. Meetsma, S.I. Troyanov, B. Hessen, J.H. Teuben, Organometallics 21 (2002) 1759;

(h) J.H. Xie, L.X. Wang, Y. Fu, S.F. Zhu, B.-M. Fan, H.F. Duan, Q.L. Zhou, J. Am. Chem. Soc. 125 (2003) 4404.

[4] (a) W.D. Cotter, L. Barbour, K.L. McNamara, R. Hechter, R.J. Lachicotte, J. Am. Chem. Soc. 120 (1998) 11016;

(b) M.H. Chisholm, S.T. Haubrich, J.C. Huffman, W.E. Streib, J. Am. Chem. Soc. 119 (1997) 1634;

(c) T. Itoh, K. Mitsukura, N. Ishida, K. Uneyama, Org. Lett. 2 (2000) 1431;

(d) T.L. Choi, C.W. Lee, A.K. Chatterjee, R.H. Grubbs, J. Am. Chem. Soc. 123 (2001) 10417; (e) L. Jafarpour, S.P. Nolan, Organometallics 19 (2000) 2055;

(f) Y.M. Ahn, K. Yang, G.I. Georg, Org. Lett. 3 (2001) 1411;

(g) M.S. Sanford, M. Ulman, R.H. Grubbs, J. Am. Chem. Soc. 123 (2001) 749 ;

(h) A.E. Sutton, B.A. Seigal, D.F. Finnegan, M.L. Snapper, J. Am. Chem. Soc. 124 (2002) 13390;

(i) S. Fomine, S.M. Vargas, M.A. Tlenkopatchev, Organometallics 22 (2003) 93

[5] (a) J.E. Mcalvin, C.L. Fraser, Macromolecules 32 (1999) 6925;

(b) P.S. Wolfe, K.B. Wagener, Macromolecules 32 (1999) 7961;

(c) M. Kamigaito, Y. Watanabe, T. Ando, M. Sawamoto, J. Am. Chem. Soc. 124 (2002) 9945;

(d) S. Hamasaki, M. Kamigaito, M. Sawamoto, Macromolecules 35 (2002) 2934;

(e) L. Delaude, A. Demonceau, A.F. Noels, Macromolecules 36 (2003) 1446 ;

(f) C. Bianchini, G. Mantovani, A. Meli, F. Migliacci, F. Laschi, Organometallics 22 (2003) 2545.

[6] (a) P.C. Ting, Y.C. Lin, M.C. Cheng, Y. Wang, Organometallics 13 (1994) 2150;

(b) P.C. Ting, Y.C. Lin, G.H. Lee, M.C. Cheng, Y. Wang, J. Am. Chem. Soc. 118 (1996) 6433;

(c) Y.H. Lo, Y.C. Lin, G.H. Lee, Y. Wang, Organometallics 18 (1999) 982 ;

(d) C.W. Chang, Y.C. Lin, G.H. Lee, Y. Wang, Organometallics 19 (2000) 3211 ;

(e) C.C. Huang, Y.C. Lin, S.L. Huang, Y.H. Liu, Y. Wang, Organometallics 22 (2003) 1512.

[7] (a) J.Y. Yang, Y.H. Lo, S.L. Huang, Y.C. Lin, Organometallics 20 (2001) 3621 ;

(b) Y.H. Lo, Y.C. Lin, G.H. Lee, Y. Wang, Eur. J. Inorg. Chem. 23 (2004) 4616

[8] (a) M. Nakamura, N. Isobe, E. Nakamura, Chem. Rev. 103 (2003) 1295 ;

(b) I. Nakamura, G.B. Bajracharya, Y. Yamamoto, J. Org. Chem. 68 (2003) 2297 ;

(c) L. Liao, J.M. Fox, J. Am. Chem. Soc. 124 (2002) 14322;

(d) P.W. Jennings, L.L. Johnson, Chem. Rev. 94 (1994) 2241

[9] A. Padwa, Acc. Chem. Res. 9 (1976) 371.

[10] (a) Z.P. Demko, K.B. Sharpless, J. Org. Chem. 66 (2001) 7945;

(b) E.D. Soli, P.J. Deshong, J. Org. Chem. 64 (1999) 9724;

(c) A. Dondoni, M.C. Scherrmann, A. Marra, J.L. Delépine, J. Org. Chem. 59 (1994) 7517;

(d) R.M. Moriarty, R.K. Vaid, T.E. Hopkin, B.K. Vaid, A. Tuncay, Tetrahedron Lett. 30 (1989) 3019;

(e) P. Magnus, J. Lacour, J. Am. Chem. Soc. 114 (1992) 3993;

(f) Y. Kita, H. Tohma, M. Inagaki, K. Hatanaka, T. Yakura, Tetrahedron Lett. 32 (1991) 4321.

[11] (a) R.H. Wiley, K.F. Hussung, J. Moffat, J. Org. Chem. 21 (1956) 190; (b) R.J.D. Pasquale, C.D. Padgett, R.W. Rosser, J. Org. Chem. 40 (1975) 810;

(c) S. Kamijo, T. Jin, Z. Huo, Y. Yamamoto, Tetrahedron Lett. 43 (2002) 9707 ;

(d) R. Shintani, G.C. Fu, J. Am. Chem. Soc. 125 (2003) 10778;

(e) W. Carruthers, Cycloaddition Reaction in Organic Synthesis, Pergamon, Oxford, 1990, p. 269;

(f) C.W. Tornøe, C. Chritensen, M. Meldal, J. Org. Chem. 67 (2002) 3057 ;

(g) K.V. Gothelf, K.A. Jørgensen, Chem. Rev. 98 (1998) 863;

(h) G. L'abbé, Chem. Rev. 69 (1969) 345.

[12] (a) S. Kamijo, T. Jin, Z. Huo, Y. Yamamoto, J. Am. Chem. Soc. 125 (2003) 7786

(b) S. Kamijo, Y. Yamamoto, Angew. Chem., Int. Ed. 41 (2002) 3230; (c) S. Kamijo, T. Jin, Y. Yamamoto, J. Am. Chem. Soc. 123 (2001) 9453;

(d) S. Kamijo, T. Jin, Y. Yamamoto, J. Org. Chem. 67 (2002) 7413.

[13] A. Palazzi, S. Stagni, S. Bordoni, M. Monari, S. Selva, Organometallics 21 (2002) 3774 
[14] (a) K.H. Chang, Y.C. Lin, Chem. Commun. (1998) 1441;

(b) K.H. Chang, Y.C. Lin, Y.H. Liu, Y.J. Wang, J. Chem. Soc., Dalton Trans. 21 (2001) 3154.

[15] A.G.M. Barrett, N.E. Carpenter, M. Sabat, J. Organomet. Chem. 352 (1988) 8.

[16] (a) G. L'Abbè, Chem. Rev. 69 (1969) 345;

(b) R.N. Butler, in: A.R. Katritzky, C.W. Rees (Eds.), Comprehensive Heterocyclic Chemistry, vol. 5, Pergamon, Oxford, 1984, p. 791 (Part 4A).
[17] R.N. Bulter, Adv. Heterocycl. Chem. 21 (1977) 323.

[18] W.P. Fehlhammer, W. Beck, Z. Naturforsch, Teil B 38 (1983) 546; J. Geisenberger, J. Erbe, J. Heidrich, U. Nagel, W. Beck, Z. Naturforsch, Teil B 42 (1987) 55.

[19] W. Beck, K. Schorpp, Chem. Ber. 108 (1975) 3317.

[20] B.T. Hsieh, J.H. Nelson, E.B. Milosavljevic, W. Beck, T. Kemmerich, Inorg. Chim. Acta 133 (1987) 267;

T. Kemmerich, J.H. Nelson, N.E. Takach, H. Bohme, B. Jablonski, W. Beck, Inorg. Chem. 21 (1982) 1226. 